\title{
Article \\ Nitric Oxide and Abscisic Acid Mediate Heat Stress Tolerance through Regulation of Osmolytes and Antioxidants to Protect Photosynthesis and Growth in Wheat Plants
}

\author{
Noushina Iqbal ${ }^{1}\left(\mathbb{D}\right.$, Zebus Sehar ${ }^{2}\left(\mathbb{D}\right.$, Mehar Fatma $^{2} \mathbb{( D}$, Shahid Umar ${ }^{1, *}$, Adriano Sofo ${ }^{3, *(D)}$ \\ and Nafees A. Khan $2, *$ (D) \\ 1 Department of Botany, Jamia Hamdard, New Delhi 110062, India; naushina.iqbal@gmail.com \\ 2 Plant Physiology and Biochemistry Laboratory, Department of Botany, Aligarh Muslim University, \\ Aligarh 202002, India; seharzebus5779@gmail.com (Z.S.); meharfatma30@gmail.com (M.F.) \\ 3 Department of European and Mediterranean Cultures: Architecture, Environment, \\ Cultural Heritage (DiCEM), University of Basilicata, Via Lanera, 75100 Matera, Italy \\ * Correspondence: sumer@jamiahamdard.ac.in (S.U.); adriano.sofo@unibas.it (A.S.); \\ naf9.amu@gmail.com (N.A.K.)
}

check for

updates

Citation: Iqbal, N.; Sehar, Z.; Fatma,

M.; Umar, S.; Sofo, A.; Khan, N.A.

Nitric Oxide and Abscisic Acid Mediate Heat Stress Tolerance through Regulation of Osmolytes and Antioxidants to Protect

Photosynthesis and Growth in Wheat Plants. Antioxidants 2022, 11, 372.

https://doi.org/10.3390/ antiox11020372

Academic Editor: Stanley Omaye

Received: 26 January 2022

Accepted: 11 February 2022

Published: 12 February 2022

Publisher's Note: MDPI stays neutral with regard to jurisdictional claims in published maps and institutional affiliations.

Copyright: (c) 2022 by the authors. Licensee MDPI, Basel, Switzerland. This article is an open access article distributed under the terms and conditions of the Creative Commons Attribution (CC BY) license (https:// creativecommons.org/licenses/by/ $4.0 /)$.

\begin{abstract}
Nitric oxide (NO) and abscisic acid (ABA) play a significant role to combat abiotic stress. Application of $100 \mu \mathrm{M}$ sodium nitroprusside (SNP, NO donor) or ABA alleviated heat stress effects on photosynthesis and growth of wheat (Triticum aestivum L.) plants exposed to $40^{\circ} \mathrm{C}$ for 6 h every day for 15 days. We have shown that ABA and NO synergistically interact to reduce the heat stress effects on photosynthesis and growth via reducing the content of $\mathrm{H}_{2} \mathrm{O}_{2}$ and thiobarbituric acid reactive substances (TBARS), as well as maximizing osmolytes production and the activity and expression of antioxidant enzymes. The inhibition of NO and ABA using c-PTIO (2-4 carboxyphenyl-4,4,5,5tetramethylimidazoline-1-oxyl-3-oxide) and fluridone (Flu), respectively, reduced the osmolyte and antioxidant metabolism and heat stress tolerance. The inhibition of NO significantly reduced the ABA-induced osmolytes and antioxidant metabolism, exhibiting that the function of ABA in the alleviation of heat stress was NO dependent and can be enhanced with NO supplementation.Thus, regulating the activity and expression of antioxidant enzymes together with osmolytes production could act as a possible strategy for heat tolerance.
\end{abstract}

Keywords: abscisic acid; glycine-betaine; nitric oxide; proline; total soluble sugar; trehalose

\section{Introduction}

The rise in temperature beyond the plants' optimal requirement for growth is one of the most serious abiotic stressors causing irreparable harm to the development of plants [1,2]. Climate change is expected to significantly affect agriculture and food security [3]. It has been estimated that a gradual expected rise in the global temperature may influence plant productivity prominently, particularly in the next decades [4]. The average world temperature over the next 20 years may reach or exceed $1.5^{\circ} \mathrm{C}$ of warming. At $2{ }^{\circ} \mathrm{C}$ of global warming, heat extremes would more often reach critical tolerance thresholds for agriculture and health according to the Intergovernmental Panel on Climate Change [5]. Among the alterations, excessive temperature stress during the crop reproductive phase has a likely detrimental influence on agricultural productivity [6,7]. It has been shown that high temperatures adversely affected plant molecular, biochemical, and physiological characteristics [8-13]. Heat stress causes an oxidative burst, membrane lipid peroxidation, pigment bleaching, protein degradation, enzyme inactivation, and macromolecule damage in plants $[2,14-16]$. It influences cell differentiation and elongation, cytoskeleton degradation [2,17], and the activity of chloroplasts [18].

The plant's reaction to heat stress depends on its developmental stage and the severity of the stress $[19,20]$. Devasirvatham et al. [21] showed that higher temperaturestress 
during anthesis resulted in more aborted and deformed buds, while heat stress during the vegetative stage negatively influenced plant's growth, morphology, and nutrient absorption. However, the optimal temperature varies across compartments within the cell and between species within the genus [22]. A recent research on 12 cultivars of Oryza sativa has shown a negative and differential impact of high night temperature on plant metabolism [23]). As a result, plant scientists are focused on discovering signaling molecules that have the potential to shield plants against the negative impacts of climate change [24-26]. Exogenous application of osmoprotectants, phytohormones, signaling molecules, and trace elements has demonstrated to benefit plants in high temperature environments, owing to their growth-promoting and antioxidant properties [27-30].

Nitric oxide (NO) is gaining growing interest from the plant science community due to its participation in the resistance to diverse plant stress situations; however, its effects on heat stress tolerance are still debatable. It is a free radical gaseous molecule that has been shown to be involved in diverse biological functions in plants [31]. Nitric oxide is an excellent diffusible chemical messenger in plant signaling due to the fact that it is a small diatomic molecule with a short half-life and lacks charge [32]. Over time, evidence developed that NO plays a vital function in a variety of plant physiological processes, including seed germination [33,34], senescence and maturation [35], and multiple abiotic stress responses [36,37]. Several researchers have focused on explaining the critical function of NO in modulating different plant hormone-mediated growth and stress responses [12,38-41]. NO might act as a secondary messenger for the other protective compound. Diao et al. [42] found that NO was induced by spermidine in tomato under chilling stress and was responsible for chilling tolerance because its inhibition inhibited tolerance. NO could be a common signaling component for various elicitors and phytohormones, including ABA [43]; therefore, its crosstalk is important. Apart from NO, abscisic acid (ABA) also plays a pivotal role in the plant's response to various abiotic stresses, such as heat, water deficit, and salinity, and regulates stomatal closure and production of several acclimation proteins [44,45]. Teplova et al. [46] reported that ABA content was increased in response to heat exposure in tobacco plant. Gong et al. [47] have reported that thermotolerance induced by ABA supplementation in maize was mediated by $\mathrm{Ca}^{2+}$ and associated with antioxidant systems. ABA-responsive marker genes were implicated in heat tolerance which include AREB1 (ABA response element-binding protein 1), LTP1 (lipid transfer protein 1), and DREB3 (dehydration-responsive element-binding protein 3), and were also increased in NtDOG1L-T transgenic lines in tobacco under heat stress to induce heat tolerance [48].

The interaction between NO and ABA under heat stress has been reviewed [49]. Nitric oxide triggers antioxidant gene expression or activates antioxidant enzymes through posttranslational modifications for stress tolerance [50]. In wheat, Alnusairi et al. [51] reported that treatment with NO increased the accumulation of proline and soluble sugars and also upregulated the antioxidant system in order to reduce salt-induced oxidative damage on membranes. Nitic oxide was found to decrease the superoxide dismutase/ascorbate peroxidase (SOD/APX) ratio to eliminate Al-induced excess hydrogen peroxide $\left(\mathrm{H}_{2} \mathrm{O}_{2}\right)$ and malondialdehyde (MDA) to prevent programmed cell death in peanut root tips [52]. Ahmad et al. [53] reported the role of NO in salt tolerance via enhancing the expression of $S O D$, $A P X$, and glutathine reductase (GR), together with increased accumulation of osmolytes.

Similarly, Guan et al. [54] found ABA role in regulating the expression of the Cat1 gene during late maize embryogenesis under osmotic stress in maize. Zhang et al. [55] found a $\mathrm{C}_{2} \mathrm{H}_{2}$-type zinc finger protein, ZFP36, for ABA-induced antioxidant defense, which resulted in rice tolerance to water stress and oxidative stress. ABA-induced antioxidant defense in maize was responsible for drought and heat tolerance via HSP70 [56]. ABA was required for expression of the P5CS gene during salt stress in Arabidopsis [57]. Studies have reported the role of proline, glycine betaine (GB), and calcium in thermotolerance and their induction by ABA $[47,58,59]$ and $\mathrm{NO}$ [60]. Nitric oxide was found to increase the synthesis of ABA in wheat seedlings exposed to salt stress and acted downstream of ABA 
in ABA-induced proline accumulation [61]. Nitric oxide is also reported to enhance proline accumulation under salt stress [62] and osmotic stress [63]. Reports suggest that NO was required for the ABA-dependent proline formation under salt stress [61]. Li et al. [64] found that $\mathrm{H}_{2} \mathrm{~S}$ increases trehalose accumulation under heat stress, which helps heat tolerance.

Wheat is an economically important crop that provides nutrition to the population. It is an important cereal crop and rich source of proteins, vitamins, and dietary fibers, as well as a source of food for many developing countries worldwide [65]. It is the largest food crop, producing 776.1 million tons of grains to add to the world crop production [66]. The demand for wheat is increasing and a $2.0 \%$ annual increase is predicted [67]; however, is threatened by heat and water stress [68]. Heat stress reduces its photosynthetic potential and growth $[69,70]$ and affects wheat's physiological, biological, and biochemical processes [71]. The present study explored the interaction between NO and ABA in mitigating heat stress in the wheat crop through their impact on osmolytes accumulation and the activity and expression of antioxidant enzymes.

In this research, we investigated their individual and interactive effect under heat stress in wheat through regulation of osmolytes and antioxidants. As the hormonal action is interrelated through a cascade of signaling molecules, we have shown the coordination of NO and ABA in heat stress tolerance, with major emphasis on osmolytes and antioxidants. Such a study, where the importance of antioxidants and osmolytes is shown in photosynthetic protection through $\mathrm{ABA}$ and $\mathrm{NO}$ involvement, has not been done.

\section{Materials and Methods}

\subsection{Plant Material and Growth Conditions}

Seeds of wheat (Triticum aestivum L.) cultivar WH542 obtained from the National Seeds Corporation, New Delhi, India, were surface sterilized with $0.01 \% \mathrm{HgCl}_{2}$ followed by repeated washing with double-distilled water. The seeds were then sown in acid-washed purified sand in pots of $23-\mathrm{cm}$ in diameter. The pots were placed in an environmental growth chamber (Khera-Instruments, New Delhi, India) with day/night temperatures at $25 / 18^{\circ} \mathrm{C}, 12 \mathrm{~h}$ photoperiod (PAR $300 \mu \mathrm{mol} \mathrm{m}^{-2} \mathrm{~s}^{-1}$ ), and relative humidity of $65 \pm 5 \%$. Two plants per pot were maintained and $150 \mathrm{~mL}$ of full-strength Hoagland's nutrition solution was applied alternate days. After seedling emergence (10 days after sowing, DAS), the plants were subjected to temperature stress treatment by keeping them at $40^{\circ} \mathrm{C}$ for $6 \mathrm{~h}$ every day for 15 days with all other growth conditions remaining the same, after which they were allowed to recover at the optimal temperature $\left(25^{\circ} \mathrm{C}\right)$ and grown for the experimental period. The control plants were maintained at $25^{\circ} \mathrm{C}$ throughout the experimental growth period (30 days). To investigate the role of $\mathrm{NO}$ and $\mathrm{ABA}$ in mitigating the adverse effects of high temperature stress, sodium nitroprusside (SNP, NO donor) and ABA, each at $100 \mu \mathrm{M}$ concentration, were applied on the foliage of plants either alone or in combination, with a hand sprayer at 10 DAS; i.e., before heat stress. A $0.5 \%$ teepol as surfactant was added with the treatments spray including control which received spray of double distilled water. To understand the contribution of the effect of NO and ABA, their inhibitors CPTIO (2-4 carboxyphenyl-4,4,5,5-tetramethylimidazoline-1-oxyl-3-oxide, NO scavenger) at $100 \mu \mathrm{M}$ and fluridone (Flu, ABA biosynthesis inhibitor) at $80 \mu \mathrm{M}$, respectively, were applied at 10 DAS with NO/ABA treatments. The concentrations of SNP and ABA were determined based on the study of Iqbal et al. [70] and Wu et al. [72], respectively. The spray volume of the chemicals was approximately $30 \mathrm{~mL}$. The treatments were arranged in a randomly blocked design with four replicates $(n=4)$ for each treatment. At 30 DAS, plants were sampled for different measurements.

\subsection{Determination of Growth Characteristics}

Plants were uprooted and washed gently under running tap water to remove the adhering sand. Plants were then blotted with soft paper towel to remove any free moisture. Plant length was measured on a meter scale. Fresh weight of plants was determined using an electronic balance, while dry weight of the plants was recorded after drying the sample 
in a hot air oven at $80{ }^{\circ} \mathrm{C}$ for $72 \mathrm{~h}$ until reaching a constant weight. Leaf area was measured by using leaf area meter (LA211, Systronic, New Delhi, India).

\subsection{Photosynthetic Characteristics Measurements}

The fully expanded third leaf of each treatment was taken for gas exchange measurements. An infrared gas analyzer (CID-340, Photosynthesis System, Bio-science, Washington, DC, USA) was used for measurements of net photosynthesis $\left(\mathrm{P}_{\mathrm{N}}\right)$, stomatal conductance (gs), and intercellular $\mathrm{CO}_{2}$ concentration $(\mathrm{Ci})$. The details of the method are given in Supplementary File S1. Chlorophyll content was measured with a SPAD chlorophyll meter (SPAD 502 DL PLUS, Konica Minolta, Japan).

The maximal efficiency of photosystem II (PSII), as given by Fv/Fm, was determined with a chlorophyll fluorometer (Junior-PAM, Heinz Walz, GmbH, Effeltrich, Germany). The process is detailed in Supplementary File S1.

Ribulose 1,5-bisphosphate carboxylase/oxygenase (Rubisco, EC 4.1.1.39) activity was spectrophotometrically determined by adopting the method of Usuda [73]. The details are given in Supplementary File S1.

\subsection{Determination of $\mathrm{H}_{2} \mathrm{O}_{2}$ and Thiobarbituric Acid Reactive Substance (TBARS) Content}

Content of $\mathrm{H}_{2} \mathrm{O}_{2}$ was determined by adopting the method of Okuda et al. [74]. Lipid peroxidation was determined by measuring the content of thiobarbituric acid reactive substance (TBARS), as described by Dhindsa et al. [75]. The details of the procedures are given in Supplementary File S1.

\subsection{Abscisic Acid Content}

The ABA content was determined by adopting the method of Hung and Kao [76], with slight modifications. The details of the procedure are mentioned in Fatma et al. [77]. ABA was determined spectrophotometrically at $405 \mathrm{~nm}$ with an ABA immunoassay detection kit (model PGR-1; Sigma-Aldrich, St. Louis, MO, USA).

\subsection{Determination of NO Generation}

Nitric oxide generation was confirmed by estimating the nitrite content by adopting the method of Zhou et al. [78], with slight modifications. The details of the method are presented in Gautam et al. [12]. The absorbance of the reaction mixture was read at $540 \mathrm{~nm}$ and NO content was estimated from a calibration curve plotted using sodium nitrite as standard.

\subsection{Assay of Activity of Antioxidant Enzymes}

The top-most leaves were used to get $200 \mathrm{mg}$ of fresh leaf tissue and it was rapidly grounded in ice-cold extraction buffer and centrifuged at $15,000 \times g$ for $20 \mathrm{~min}$ at $4{ }^{\circ} \mathrm{C}$. The supernatant was used for the assay of enzymes. Protein was estimated following the Bradford [79] method utilizing bovine serum albumin as a protein standard. Complete detail of the extraction buffer and method is given in Supplementary File S1.

The Beyer and Fridovich [80] and Giannopolitis and Ries [81] methods were used for determining superoxide dismutase (SOD) activity in the protein extracts based on inhibition of the photochemical reduction of nitro blue tetrazolium (NBT). The Aebi [82] method with slight modification was adopted for observing the disappearance of $\mathrm{H}_{2} \mathrm{O}_{2}$ at $240 \mathrm{~nm}$ for determination of the catalase (CAT) activity. For the assay of ascorbate peroxidase (APX), the Nakano and Asada [83] method was adopted, and the glutathione reductase (GR) activity was estimated following the method of Foyer and Halliwell [84]. The oxidation of nicotinamide adenine dinucleotide phosphate (NADPH) at $340 \mathrm{~nm}$ was monitored in the presence of glutathione (GSH). The details of method adopted for measuring the activity of antioxidant enzymes are given in Supplementary File S1. 


\subsection{Determination of Proline Content}

Proline content was estimated in the leaves using the method of Bates et al. [85]. Fresh leaf tissue $(300 \mathrm{mg}$ ) was homogenized in $3.0 \mathrm{~mL}$ of $3 \%$ sulphosalicylic acid, and the homogenate was centrifuged at $11,500 \times g$ for $12 \mathrm{~min}$. The supernatant filtrate was added to a test tube with $2.0 \mathrm{~mL}$ acid ninhydrin and $2.0 \mathrm{~mL}$ glacial acetic acid and incubated in water bath at $100{ }^{\circ} \mathrm{C}$ for $1 \mathrm{~h}$. Later, $4.0 \mathrm{~mL}$ toluene was added to the reaction mixture and mixed vigorously with stirrer for 20-30 s, and then left to stand for 5-10 min. The absorbance of the reddish pink upper phase was measured on a spectrophotometer at $520 \mathrm{~nm}$ using L-proline as a standard.

\subsection{Determination of Glycine Betaine Content}

The estimation of glycine betaine (GB) in leaves was based on the formation of the betaine-periodite complex by adopting the method of Grieve and Grattan [86]. The details of the procedure are given in Syeed et al. [87].

\subsection{Estimation of Total Soluble Sugar and Trehalose Content}

The method of Xu et al. [88] and Gautam et al. [13] were adopted for estimation of total soluble sugar content. Trehalose content in leaves was determined following the method described by Li et al. [64], with some modifications. The details of the procedure done are given in Supplementary File S1.

\subsection{Quantitative RT-PCR Analysis}

Total RNA extraction for gene expression was done in fresh leaves (100 $\mathrm{mg}$ ) of four biological samples of plants subjected to different treatments using Trizol reagent according to the instructions given in the kit (Ambion, Life Technologies, Austin, TX, USA). The specific primers were designed to assess gene expression. All reactions were performed as three biological replicates (with four technical replicates of each), using gene-specific primers and actin primers as an internal control. The results were presented as the expression of the gene of interest in relation to the internal control in the treated sample compared with corresponding values in the untreated control.The primer pairs used for quantitative RT-PCR and the details of the procedure are provided in Supplementary File S1.

\subsection{Statistical Analysis}

The data were statistically analyzed using Analysis of variance (ANOVA) with the help of software SPSS 17.0 for Windows (SPSS Inc., Chicago, IL, USA). Data were presented as the mean $\pm \mathrm{SE}(n=4)$ and the significant differences were identified on the basis of the Tukey test at $p<0.05$.

\section{Results}

We tested the individual and combined effect of $\mathrm{NO}$ and ABA in heat stress alleviation. The combined NO and ABA treatment under heat stress was also subjected to $100 \mu \mathrm{M}$ cPTIO or $80 \mu \mathrm{M}$ fluridone at 30 DAS.

\subsection{Effect of $N O$ and $A B A$ on Growth Parameters under Heat Stress}

The indices of growth-plant length, leaf area, and plant fresh and dry weights-were analyzed under heat stress. The relative data are shown in Table 1 . Heat stress decreased plant length by $21.3 \%$, leaf area by $32.7 \%$, plant fresh weight by $25.0 \%$, and plant dry weight by $51.6 \%$ in comparison to the control plants. Individual application of $\mathrm{NO}$ and ABA increased the indices of growth. However combined application of NO and ABA maximally increased these parameters by $17.1 \%, 42.7 \%, 28.6 \%$, and $58.3 \%$, respectively, in comparison to the control plants. Supplementation of NO/ABA exhibited an increase in growth indices of plant by decreasing the negative effects caused by heat stress. Moreover, the combined application of NO and ABA significantly alleviated the effect of heat stress and increased plant length by $37.8 \%$, leaf area by $76 \%$, plant fresh weight by $38 \%$, and 
plant dry weight by $177 \%$ in comparison to the heat-stressed plants. Both cPTIO and Flu inhibited the increase observed in growth parameters with NO and ABA under heat stress. Supplementation of Flu to the plants receiving NO and ABA under heat stress alleviated the effect of heat stress and increased these parameters by $27 \%, 49.1 \%, 28.6 \%$, and $134 \%$, respectively, in comparison to the heat-stressed plants. Moreover, cPTIO treatment to plants receiving NO and ABA under heat stress showed less alleviation of heat stress and increased these parameters by $8.1 \%, 7.1 \%, 4.8 \%$, and $20.5 \%$, respectively, compared to the plants exposed to heat stress. The response of plants to inhibitors exhibited that the action of ABA in heat tolerance was through NO action (Table 1; Figure 1).

Table 1. Plant length, leaf area, plant fresh weight, and plant dry weight of wheat (Triticum aestivum $\mathrm{L}$. var. WH 542) treated with $100 \mu \mathrm{M} \mathrm{SNP}$ and/or ABA in the presence $\left(40^{\circ} \mathrm{C}\right)$ or absence $\left(25^{\circ} \mathrm{C}\right)$ of heat stress at 30 days after sowing (DAS). The combined $\mathrm{NO}$ and ABA treatment under heat stress was also subjected to $100 \mu \mathrm{M}$ cPTIO or $80 \mu \mathrm{M}$ fluridone at 30 DAS. Data are presented as the treatment mean $\pm \mathrm{SE}(n=4)$. In each column, data followed by the same letter are not significantly different by Tukey test at $p<0.05$. ABA, abscisic acid; CPTIO, 2-4-carboxyphenyl-4,4,5,5-tetramethylimidazoline-1oxyl-3-oxide; Flu, fluridone; HT, heat stress; SNP, sodium nitroprusside.

\begin{tabular}{ccccc}
\hline & Plant Length & $\begin{array}{c}\text { Leaf Area } \\
\text { Treatments }\end{array}$ & $\begin{array}{c}\text { Plant Fresh } \\
\text { Weight }\end{array}$ & $\begin{array}{c}\text { Plant Dry } \\
\text { Weight }\end{array}$ \\
\cline { 4 - 5 } & & & \multicolumn{2}{c}{$\mathbf{( g ~ P l a n t ~}^{-\mathbf{1}} \mathbf{)}$} \\
\hline Control & $47 \pm 2.35 \mathrm{~d}$ & $27.2 \pm 1.2 \mathrm{~d}$ & $2.8 \pm 0.14 \mathrm{~d}$ & $0.91 \pm 0.042 \mathrm{~d}$ \\
HT & $37 \pm 1.82 \mathrm{~g}$ & $18.3 \pm 0.84 \mathrm{~g}$ & $2.1 \pm 0.11 \mathrm{~g}$ & $0.44 \pm 0.017 \mathrm{~g}$ \\
SNP & $52 \pm 1.02 \mathrm{~b}$ & $33.1 \pm 1.28 \mathrm{~b}$ & $3.2 \pm 0.16 \mathrm{~b}$ & $1.29 \pm 0.060 \mathrm{~b}$ \\
ABA & $50 \pm 2.40 \mathrm{c}$ & $29.4 \pm 1.72 \mathrm{c}$ & $3.1 \pm 0.15 \mathrm{c}$ & $1.09 \pm 0.051 \mathrm{c}$ \\
SNP + ABA & $55 \pm 1.11 \mathrm{a}$ & $38.8 \pm 1.99 \mathrm{a}$ & $3.6 \pm 0.18 \mathrm{a}$ & $1.44 \pm 0.072 \mathrm{a}$ \\
HT + SNP & $48 \pm 2.36 \mathrm{~cd}$ & $28.2 \pm 1.65 \mathrm{~cd}$ & $2.6 \pm 0.13 \mathrm{~d}$ & $0.98 \pm 0.054 \mathrm{~d}$ \\
HT + ABA & $44 \pm 2.21 \mathrm{e}$ & $25.3 \pm 1.23 \mathrm{e}$ & $2.4 \pm 0.12 \mathrm{e}$ & $0.73 \pm 0.044 \mathrm{e}$ \\
HT + SNP + ABA & $51 \pm 2.49 \mathrm{~b}$ & $32.2 \pm 1.54 \mathrm{~b}$ & $2.9 \pm 0.14 \mathrm{~b}$ & $1.22 \pm 0.065 \mathrm{~b}$ \\
$\mathrm{HT}+\mathrm{SNP}+\mathrm{ABA}+\mathrm{Flu}$ & $47 \pm 2.32 \mathrm{~d}$ & $27.3 \pm 1.11 \mathrm{~d}$ & $2.7 \pm 0.13 \mathrm{~cd}$ & $1.03 \pm 0.046 \mathrm{~cd}$ \\
$\mathrm{HT}+\mathrm{SNP}+\mathrm{ABA}+\mathrm{cPTIO}$ & $40 \pm 1.98 \mathrm{f}$ & $19.6 \pm 0.98 \mathrm{f}$ & $2.2 \pm 0.11 \mathrm{f}$ & $0.53 \pm 0.033 \mathrm{f}$ \\
\hline
\end{tabular}

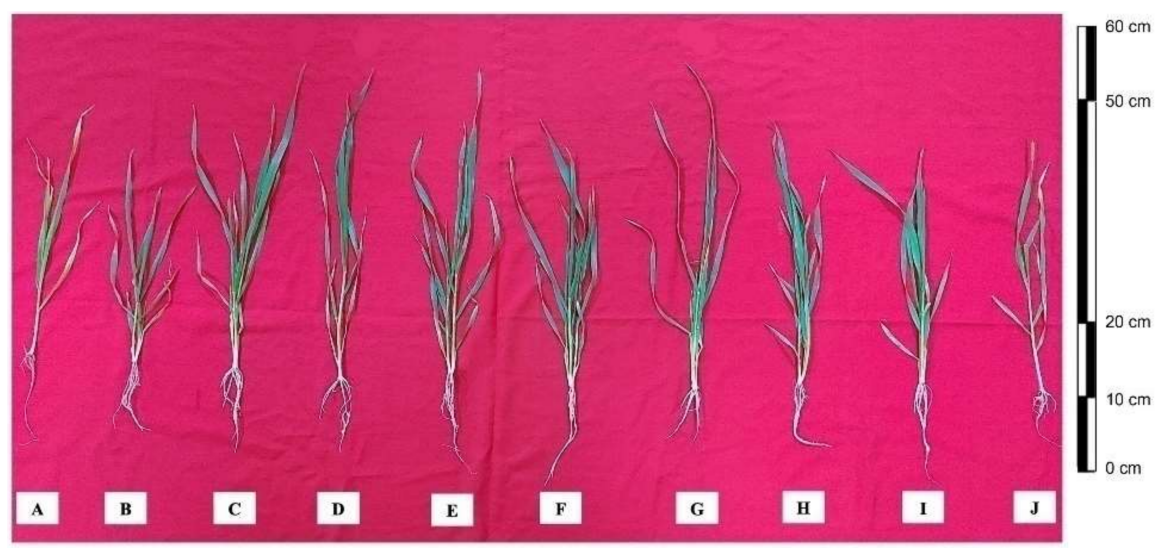

Figure 1. Leaves of wheat (Triticum aestivum L. var. WH 542) plants were treated with $100 \mu \mathrm{M}$ SNP and / or ABA in the presence $\left(40^{\circ} \mathrm{C}\right)$ or absence $\left(25^{\circ} \mathrm{C}\right)$ of heat stress at 30 days after sowing (DAS). The combined NO and ABA treatment under heat stress was also subjected to $100 \mu \mathrm{McPTIO}$ and / or $80 \mu \mathrm{M}$ fluridone (Flu) at 30 DAS. (A) control, (B) heat stress, (C) SNP, (D) ABA, (E) SNP + ABA, (F) HT + SNP, (G) $\mathrm{HT}+\mathrm{ABA},(\mathrm{H}) \mathrm{HT}+\mathrm{SNP}+\mathrm{ABA},(\mathrm{I}) \mathrm{HT}+\mathrm{SNP}+\mathrm{ABA}+\mathrm{Flu}$, and (J) HT + SNP + ABA + cPTIO. ABA, abscisic acid; cPTIO, 2-4-carboxyphenyl-4,4,5,5-tetramethylimidazoline-1-oxyl-3-oxide; Flu, fluridone; HT, heat stress; SNP, sodium nitroprusside. 
3.2. Impact of Heat Stress on Photosynthetic Characteristics and Involvement of NO and ABA in Inhibiting Heat-Induced Photosynthetic Reduction

Table 2 shows that heat stress reduced $\mathrm{P}_{\mathrm{N}}$ by $44.6 \%$, gs by $28.4 \%$, Ci by $43.6 \%$, Chl by $37.0 \%, \mathrm{Fv} / \mathrm{Fm}$ by $16.7 \%$, and Rubisco by $35.2 \%$ compared to plants grown under control conditions. Individual application of NO and ABA under non-stress conditions increased the studied photosynthetic parameters but maximal increase occurred with their combined application. In the same line, NO and ABA effectively reduced the heat stress effects on photosynthetic parameters. The increase in photosynthetic parameters due to $\mathrm{NO}$ and $\mathrm{ABA}$ under normal conditions and alleviation under heat stress were greater with NO than ABA. Application of $\mathrm{NO}$ reduced the inhibitory effect of heat stress on photosynthetic parameters to the level of control.

Table 2. Net photosynthesis, stomatal conductance, intercellular $\mathrm{CO}_{2}$ concentration, chlorophyll content, maximum efficiency of PSII, and ribulose 1,5 bisphosphate carboxylase/oxygenase (Rubisco) activity of wheat (Triticum aestivum L. var. WH 542) leaves treated with $100 \mu \mathrm{M}$ SNP and/or ABA in the presence $\left(40{ }^{\circ} \mathrm{C}\right)$ or absence $\left(25^{\circ} \mathrm{C}\right)$ of heat stress at 30 DAS. The combined NO and ABA treatment under heat stress was also subjected to $100 \mu \mathrm{M}$ cPTIO or $80 \mu \mathrm{M}$ fluridone at 30 days after sowing (DAS). Data are presented as the treatment mean \pm SE $(n=4)$. In each column, data followed by the same letter are not significantly different by Tukey test at $p<0.05$. ABA, abscisic acid; cPTIO, 2-4-carboxyphenyl-4,4,5,5-tetramethylimidazoline-1-oxyl-3-oxide; Flu, fluridone; HT, heat stress; SNP, sodium nitroprusside.

\begin{tabular}{|c|c|c|c|c|c|c|}
\hline Treatments & $\begin{array}{c}\text { Net } \\
\text { Photosynthesis } \\
(\mu \mathrm{mol} \mathrm{CO} 2 \\
\left.\mathrm{m}^{-2} \mathrm{~s}^{-1}\right)\end{array}$ & $\begin{array}{c}\text { Stomatal } \\
\text { Conductance } \\
\left(\mathrm{mmol} \mathrm{CO}_{2}\right. \\
\left.\mathrm{m}^{-2} \mathrm{~s}^{-1}\right)\end{array}$ & 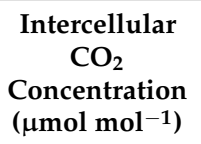 & $\begin{array}{c}\text { Chlorophyll } \\
\text { Content } \\
\text { (SPAD Value) }\end{array}$ & $\begin{array}{c}\text { Maximum } \\
\text { Quantum Yield } \\
\text { Efficiency of } \\
\text { PSII (Fv/Fm) }\end{array}$ & $\begin{array}{c}\text { Rubisco } \\
(\mu \mathrm{mol} \mathrm{CO} \\
\mathrm{mg}^{-1} \text { Protein } \\
\left.\min ^{-1}\right)\end{array}$ \\
\hline Control & $11.2 \pm 0.78 \mathrm{~d}$ & $362 \pm 16.1 d$ & $211 \pm 10.7 \mathrm{~d}$ & $30.3 \pm 1.6 \mathrm{~d}$ & $0.72 \pm 0.040 \mathrm{~d}$ & $38.9 \pm 2.1 d$ \\
\hline HT & $06.2 \pm 0.64 \mathrm{~g}$ & $259 \pm 14.3 g$ & $119 \pm 6.47 \mathrm{~g}$ & $19.1 \pm 1.4 \mathrm{~g}$ & $0.60 \pm 0.030 \mathrm{~g}$ & $25.2 \pm 1.6 \mathrm{~g}$ \\
\hline $\mathrm{NO}$ & $16.1 \pm 1.09 \mathrm{~b}$ & $433 \pm 18.9 \mathrm{~b}$ & $354 \pm 16.9 \mathrm{~b}$ & $44.2 \pm 2.8 \mathrm{~b}$ & $0.88 \pm 0.050 \mathrm{~b}$ & $53.4 \pm 2.6 \mathrm{~b}$ \\
\hline ABA & $14.6 \pm 0.84 c$ & $416 \pm 17.8 \mathrm{c}$ & $319 \pm 12.8 c$ & $40.4 \pm 2.1 c$ & $0.75 \pm 0.480 c$ & $47.8 \pm 2.4 c$ \\
\hline $\mathrm{NO}+\mathrm{ABA}$ & $18.2 \pm 0.99 a$ & $456 \pm 20.6 a$ & $376 \pm 17.19 a$ & $49.1 \pm 3.4 \mathrm{a}$ & $0.97 \pm 0.060 \mathrm{a}$ & $57.7 \pm 2.8 \mathrm{a}$ \\
\hline $\mathrm{HT}+\mathrm{NO}$ & $12.5 \pm 0.87 \mathrm{~d}$ & $356 \pm 16.8 \mathrm{~d}$ & $228 \pm 11.7 \mathrm{~d}$ & $31.8 \pm 1.8 \mathrm{~d}$ & $0.73 \pm 0.041 \mathrm{~d}$ & $40.2 \pm 2.3 d$ \\
\hline $\mathrm{HT}+\mathrm{ABA}$ & $09.8 \pm 0.84 \mathrm{e}$ & $328 \pm 15.2 \mathrm{e}$ & $191 \pm 10.8 \mathrm{e}$ & $28.6 \pm 2.1 \mathrm{e}$ & $0.66 \pm 0.036 \mathrm{e}$ & $32.7 \pm 2.2 \mathrm{e}$ \\
\hline $\mathrm{HT}+\mathrm{NO}+\mathrm{ABA}$ & $15.4 \pm 0.94 c$ & $409 \pm 18.2 c$ & $326 \pm 13.3 c$ & $39.3 \pm 1.9 c$ & $0.87 \pm 0.050 c$ & $48.1 \pm 2.4 c$ \\
\hline $\mathrm{HT}+\mathrm{NO}+\mathrm{ABA}+\mathrm{Flu}$ & $11.9 \pm 0.83 \mathrm{~d}$ & $357 \pm 15.4 d$ & $203 \pm 09.6 d$ & $31.2 \pm 1.8 \mathrm{~d}$ & $0.77 \pm 0.440 \mathrm{~d}$ & $40.6 \pm 2.2 d$ \\
\hline $\mathrm{HT}+\mathrm{NO}+\mathrm{ABA}+\mathrm{cPTIO}$ & $07.3 \pm 0.77 f$ & $302 \pm 13.9 f$ & $152 \pm 07.3 \mathrm{f}$ & $25.4 \pm 1.1 \mathrm{f}$ & $0.66 \pm 0.035 f$ & $32.5 \pm 1.8 \mathrm{f}$ \\
\hline
\end{tabular}

The interaction of $\mathrm{NO}$ and ABA in the enhancement in photosynthesis parameters was further investigated using their inhibitors. The combined NO and ABA treatment under heat stress together with Flu (ABA inhibition) resulted in bringing the photosynthetic parameters significantly equal to heat stress plus NO treatment, suggesting that inhibition of ABA did not affect NO-mediated tolerance, an indication of downstream NO signaling. On the other hand, $\mathrm{CPTIO}$ treatment to the plants receiving NO and ABA under heat stress decreased the photosynthetic parameters compared to the control (Table 2).

The photosynthetic parameters noted in NO plus heat stress treatment were significantly equal to heat stress plus NO plus ABA plus Flu treatment. Instead, when NO was inhibited by cPTIO, we observed a much more significant decrease in photosynthetic characteristics, suggesting the action of ABA being dependent on NO or ABA functions upward of NO in heat stress signaling (Table 2).

\subsection{ABA Requires NO Action for Reducing Oxidative Stress in Wheat Plants Exposed to Heat Stress}

Figure 2 shows that heat stress significantly induced high oxidative stress, which was related to the high $\mathrm{H}_{2} \mathrm{O}_{2}(+138.9 \%)$ and TBARS $(+169.1 \%)$ content compared to the control. 

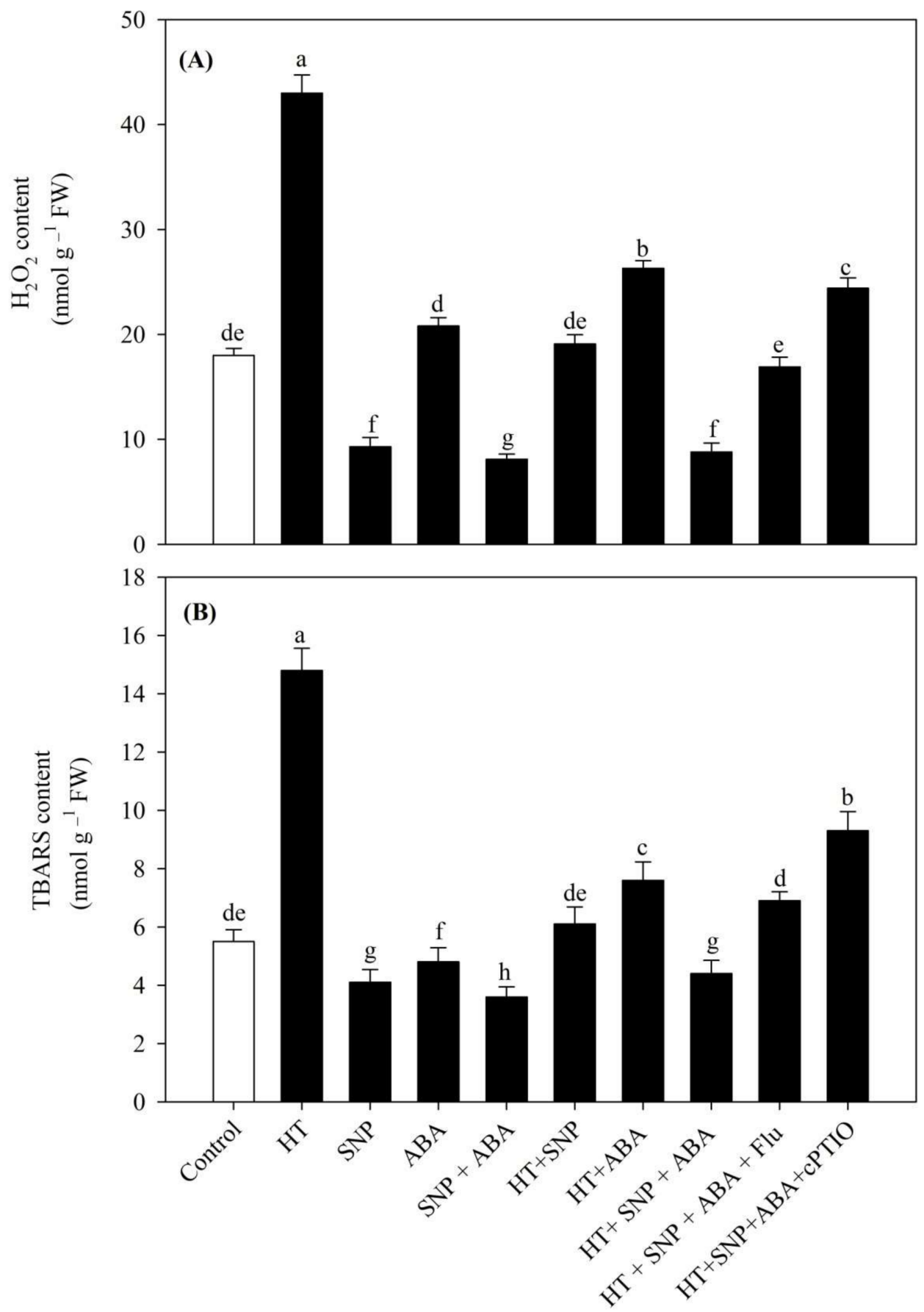

Figure 2. (A) $\mathrm{H}_{2} \mathrm{O}_{2}$ and (B) thiobarbituric acid reactive substances (TBARS) content of wheat (Triticum aestivum $\mathrm{L}$. var. WH 542) leaves treated with $100 \mu \mathrm{M} \mathrm{SNP}$ and/or ABA in the presence $\left(40{ }^{\circ} \mathrm{C}\right)$ or absence $\left(25^{\circ} \mathrm{C}\right)$ of heat stress at 30 days after sowing (DAS). The combined NO and ABA treatment under heat stress was also subjected to $100 \mu \mathrm{M}$ cPTIO and/or $80 \mu \mathrm{M}$ fluridone at 30 DAS. Data are presented as the treatment mean \pm SE $(n=4)$. Data followed by the same letter are not significantly different by Tukey test at $p<0.05$. ABA, abscisic acid; CPTIO, 2-4-carboxyphenyl-4,4,5,5tetramethylimidazoline-1-oxyl-3-oxide; Flu, fluridone; HT, heat stress; SNP, sodium nitroprusside.

NO treatment to the plants reduced oxidative stress in terms of the $\mathrm{H}_{2} \mathrm{O}_{2}$ and TBARS content by $48.3 \%$ and $25.4 \%$, whereas $\mathrm{ABA}$ increased the $\mathrm{H}_{2} \mathrm{O}_{2}$ content by $15.5 \%$ and decreased the TBARS content by $12.7 \%$, in comparison to control under no stress conditions. However, plants supplemented with $\mathrm{NO}$ and ABA showed the maximum reduction in $\mathrm{H}_{2} \mathrm{O}_{2}$ and TBARS content by $55.0 \%$ and $34.5 \%$, compared to the control. Under heat 
stress, treatment of $\mathrm{NO}$ alongwith ABA decreased the heat-induced $\mathrm{H}_{2} \mathrm{O}_{2}$ and TBARS content by $79.5 \%$ and $72.3 \%$, respectively, in comparison to the plants grown under heat stress. Application of Flu to plants receiving both ABA and NO under heat stress showed a significant decrease in oxidative stress markers, which was significantly equal to the control and also to the heat stress plus SNP treatment, suggesting that ABA inhibition has not affected a NO-mediated reduction in $\mathrm{H}_{2} \mathrm{O}_{2}$ and TBARS content. Contrarily, cPTIO alongwith combined treatment of $\mathrm{NO}$ and $\mathrm{ABA}$ plus heat showed an increase in the biomarkers of oxidative stress compared to the control. Thus, when the interaction effect was studied, it was found that the presence of $\mathrm{NO}$ has a major role in reducing oxidative stress compared to ABA and thus is responsible for the maintenance of photosynthesis under heat stress.

\subsection{Impact of Heat Stress on NO and ABA Content}

Figure 3 shows the content of $\mathrm{NO}$ and $\mathrm{ABA}$ in leaves of wheat plants exposed to heat stress. Heat stress increased the NO generation and ABA content by $135.1 \%$ and $218.6 \%$, in comparison to control plants. Under no stress conditions, individual or combined treatment of $\mathrm{NO}$ and $\mathrm{ABA}$ increased both the NO generation and $\mathrm{ABA}$ content and maximally when in combination compared to the control. Contrarily, under heat stress, plants treated with both $\mathrm{NO}$ and $\mathrm{ABA}$ showed a reduction in $\mathrm{ABA}$ and $\mathrm{NO}$ content by $37.8 \%$ and $46.1 \%$ compared to the heat stressed plants. Inhibition of $\mathrm{ABA}$ and/or NO by their biosynthesis inhibitor, such as Flu and/or cPTIO, reduced the content of NO generation by $32.4 \%$ and $60.8 \%$ and ABA content by $74.7 \%$ and $22.6 \%$, respectively, compared to the heat-stressed plants.

\subsection{The Combined Application of NO and ABA Stimulated Antioxidant Enzyme Activity under Heat Stress}

Table 3 shows that heat stress increased the activity of antioxidant enzymes such as SOD, CAT, APX, and GR by $54.7 \%, 19.6 \%, 68.2 \%$, and $62.4 \%$, respectively, in comparison to control plants. Individual application of $\mathrm{NO}$ and $\mathrm{ABA}$ also increased the antioxidant enzyme activity, which was maximally increased when both ABA and NO were applied together under no stress.

Under heat stress, treatment of $\mathrm{NO}$ alongwith $\mathrm{ABA}$ stimulated the increase in activity of SOD by $74 \%$, CAT by $42 \%$, APX by $121.6 \%$, and GR by $72 \%$, relative to the hightemperature-treated plants. However, upon application of Flu to NO plus ABA under heat stress, the activity of these antioxidant enzymes was reduced compared to NO plus ABA treatment under heat stress. A further reduction in the activity of the antioxidant enzymes occurred when $\mathrm{CPTIO}$ was applied to a combined $\mathrm{NO}$ and ABA treatment under heat stress and was significantly equal to the heat stress treatment.

\subsection{Osmolytes Accumulation Increased under Heat Stress Maximally with Combined NO and ABA Supplementation}

Osmolytes accumulation increased under heat stress due to the activation of stress signaling pathways and minimized oxidative damage and growth restriction with the increase in photosynthesis efficiency. We studied proline, GB, trehalose, and total soluble sugar content for their role in defense against heat stress (Figure 4). Heat stress triggered proline accumulation and increased it by $21 \%$, GB by $45.5 \%$, and trehalose by $24 \%$, but decreased the total soluble sugar content by $12.3 \%$, relative to the control. Treatment with individual $\mathrm{NO}$ and $\mathrm{ABA}$ led to even more substantial increase in osmolyte content and maximally when plants were treated with both $\mathrm{NO}$ and $\mathrm{ABA}$ together. Under heat stress, application of $\mathrm{NO}$ and $\mathrm{ABA}$ resulted in a significant increase in osmolyte accumulation, such as the proline content by $113.3 \%$, GB content by $56.2 \%$, trehalose content by $90 \%$, and total soluble sugar content by $40.2 \%$, relative to the heat-stressed plants. Moreover, treatment of Flu to the plants receiving $\mathrm{NO}$ and $\mathrm{ABA}$ under heat stress further increased the osmolyte content, while addition of cPTIO to the plants supplemented with $\mathrm{NO}$ and ABA under heat stress showed a reduction in the respective parameters in comparison to the high-temperature-treated plants. The reduction in the content of osmolytes occurred 
with both $\mathrm{NO}$ and $\mathrm{ABA}$ inhibition when compared to their combined application under heat stress; however, Flu caused a lesser reduction compared to CPTIO, indicative of ABA requiring $\mathrm{NO}$ for its action.
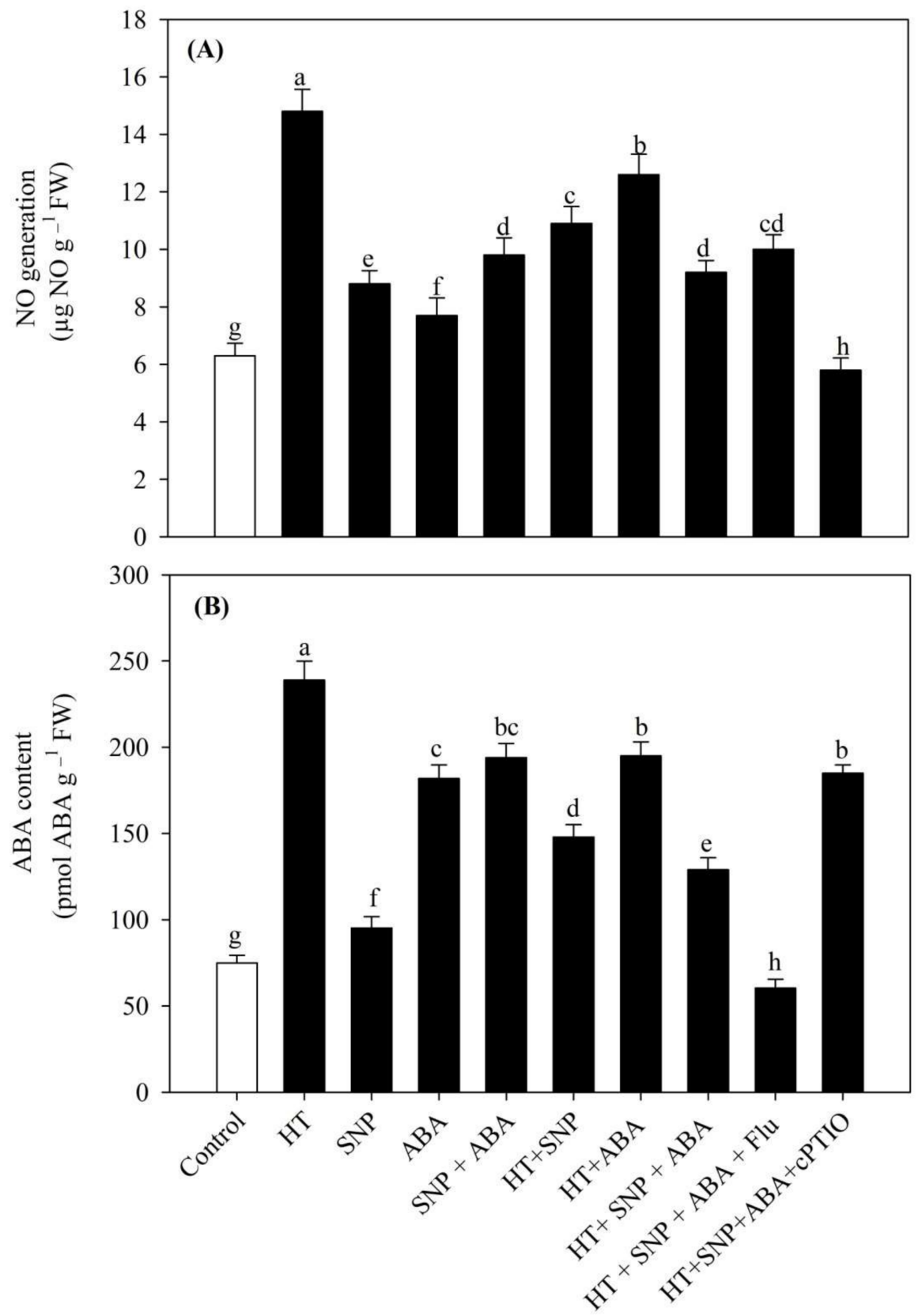

Figure 3. (A) Nitric oxide generation and (B) ABA content of wheat (Triticum aestivum L. var. WH 542) leaves treated with $100 \mu \mathrm{M}$ SNP and/or ABA in the presence $\left(40^{\circ} \mathrm{C}\right)$ or absence $\left(25^{\circ} \mathrm{C}\right)$ of heat stress at 30 days after sowing (DAS). The combined NO and ABA treatment under heat stress was also subjected to $100 \mu \mathrm{M}$ cPTIO and/or $80 \mu \mathrm{M}$ fluridone at 30 DAS. Data are presented as the mean $\pm \mathrm{SE}$ $(n=4)$. Data followed by the same letter are not significantly different by Tukey test at $p<0.05$. ABA, abscisic acid; cPTIO, 2-4-carboxyphenyl-4,4,5,5-tetramethylimidazoline-1-oxyl-3-oxide; Flu, fluridone; HT, heat stress; SNP, sodium nitroprusside. 
Table 3. Activity of superoxide dismutase (SOD), catalase (CAT), ascorbate peroxidase (APX), and glutathione reductase (GR) of wheat (Triticum aestivum L. var. WH 542) leaves treated with $100 \mu \mathrm{M}$ SNP and/or ABA in the presence $\left(40^{\circ} \mathrm{C}\right)$ or absence $\left(25^{\circ} \mathrm{C}\right)$ of heat stress at 30 days after sowing (DAS).The combined $\mathrm{NO}$ and ABA treatment under heat stress was also subjected to $100 \mu \mathrm{M} \mathrm{CPTIO}$ or $80 \mu \mathrm{M}$ fluridone at 30 days after sowing (DAS). Data are presented as the treatment mean $\pm \mathrm{SE}$ $(n=4)$. In each column, data followed by the same letter are not significantly different by Tukey test at $p<0.05$. ABA, abscisic acid; CPTIO, 2-4-carboxyphenyl-4,4,5,5-tetramethylimidazoline-1-oxyl-3-oxide; Flu, fluridone; HT, heat stress; SNP, sodium nitroprusside.

\begin{tabular}{ccccc}
\hline Treatments & SOD & CAT & APX & GR \\
\hline Control & $7.69 \pm 0.41 \mathrm{f}$ & $122 \pm 09.2 \mathrm{~g}$ & $2.2 \pm 0.23 \mathrm{f}$ & $2.29 \pm 0.18 \mathrm{f}$ \\
HT & $11.9 \pm 0.61 \mathrm{e}$ & $146 \pm 09.9 \mathrm{f}$ & $3.7 \pm 0.33 \mathrm{e}$ & $3.72 \pm 0.21 \mathrm{e}$ \\
SNP & $12.9 \pm 0.84 \mathrm{~d}$ & $161 \pm 10.4 \mathrm{~d}$ & $4.4 \pm 0.48 \mathrm{~d}$ & $4.11 \pm 0.27 \mathrm{~d}$ \\
ABA & $12.3 \pm 0.69 \mathrm{~d}$ & $142 \pm 10.7 \mathrm{e}$ & $3.3 \pm 0.31 \mathrm{e}$ & $3.71 \pm 0.24 \mathrm{e}$ \\
SNP + ABA & $15.1 \pm 1.21 \mathrm{c}$ & $174 \pm 11.2 \mathrm{c}$ & $5.7 \pm 0.55 \mathrm{c}$ & $4.90 \pm 0.34 \mathrm{c}$ \\
HT + SNP & $18.3 \pm 0.99 \mathrm{~b}$ & $191 \pm 12.3 \mathrm{~b}$ & $6.7 \pm 0.63 \mathrm{~b}$ & $5.80 \pm 0.43 \mathrm{~b}$ \\
HT + ABA & $15.4 \pm 1.29 \mathrm{c}$ & $169 \pm 11.9 \mathrm{c}$ & $5.3 \pm 0.43 \mathrm{c}$ & $4.70 \pm 0.45 \mathrm{c}$ \\
HT + SNP + ABA & $20.7 \pm 1.38 \mathrm{a}$ & $206 \pm 13.8 \mathrm{a}$ & $8.2 \pm 0.71 \mathrm{a}$ & $6.40 \pm 0.42 \mathrm{a}$ \\
HT + SNP + ABA + Flu & $17.7 \pm 1.17 \mathrm{~b}$ & $181 \pm 12.4 \mathrm{~b}$ & $6.1 \pm 0.39 \mathrm{~b}$ & $5.70 \pm 0.51 \mathrm{~b}$ \\
$\mathrm{HT}+\mathrm{SNP}+\mathrm{ABA}+\mathrm{cPTIO}$ & $12.0 \pm 0.72 \mathrm{de}$ & $149 \pm 11.5 \mathrm{f}$ & $3.4 \pm 0.29 \mathrm{e}$ & $3.89 \pm 0.14 \mathrm{e}$ \\
\hline
\end{tabular}

\subsection{Application of $\mathrm{NO}$ and $A B A$ on Antioxidant Enzyme Gene Expression under Heat Stress}

Exogenous application of $\mathrm{NO}$ with ABA increased the activity of antioxidant enzymes under heat stress, so we tested the changes in the expression level of APX and GR genes by the exogenous application of $\mathrm{NO}$ with ABA under heat stress, and also with their inhibitors as $100 \mu \mathrm{M}$ cPTIO and/or $80 \mu \mathrm{M}$ fluridone. The expression of $A P X$ and GR was upregulated with the combined treatments of $\mathrm{NO}$ and $\mathrm{ABA}$ under heat stress compared to the unstressed wheat plants. However, compared to Flu, cPTIO application to combined NO plus ABA under heat stress caused higher downregulation of antioxidant enzyme gene expression, suggesting that the effect of ABA was mediated via NO (Figure 5).

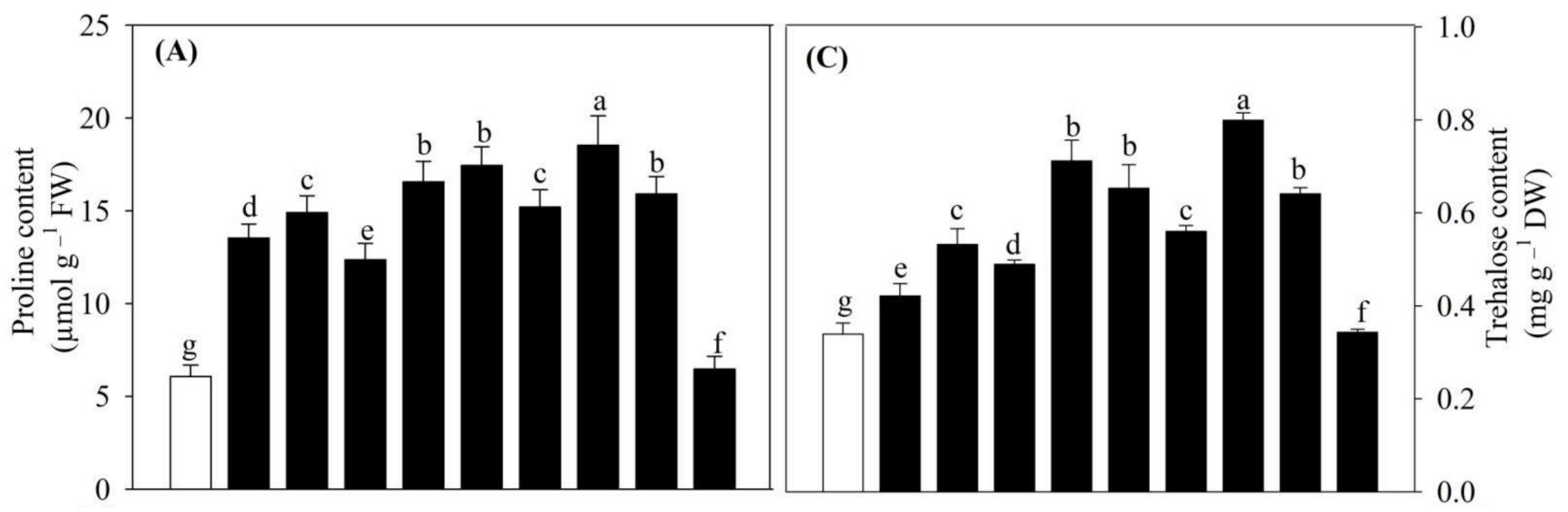

Figure 4. Cont. 


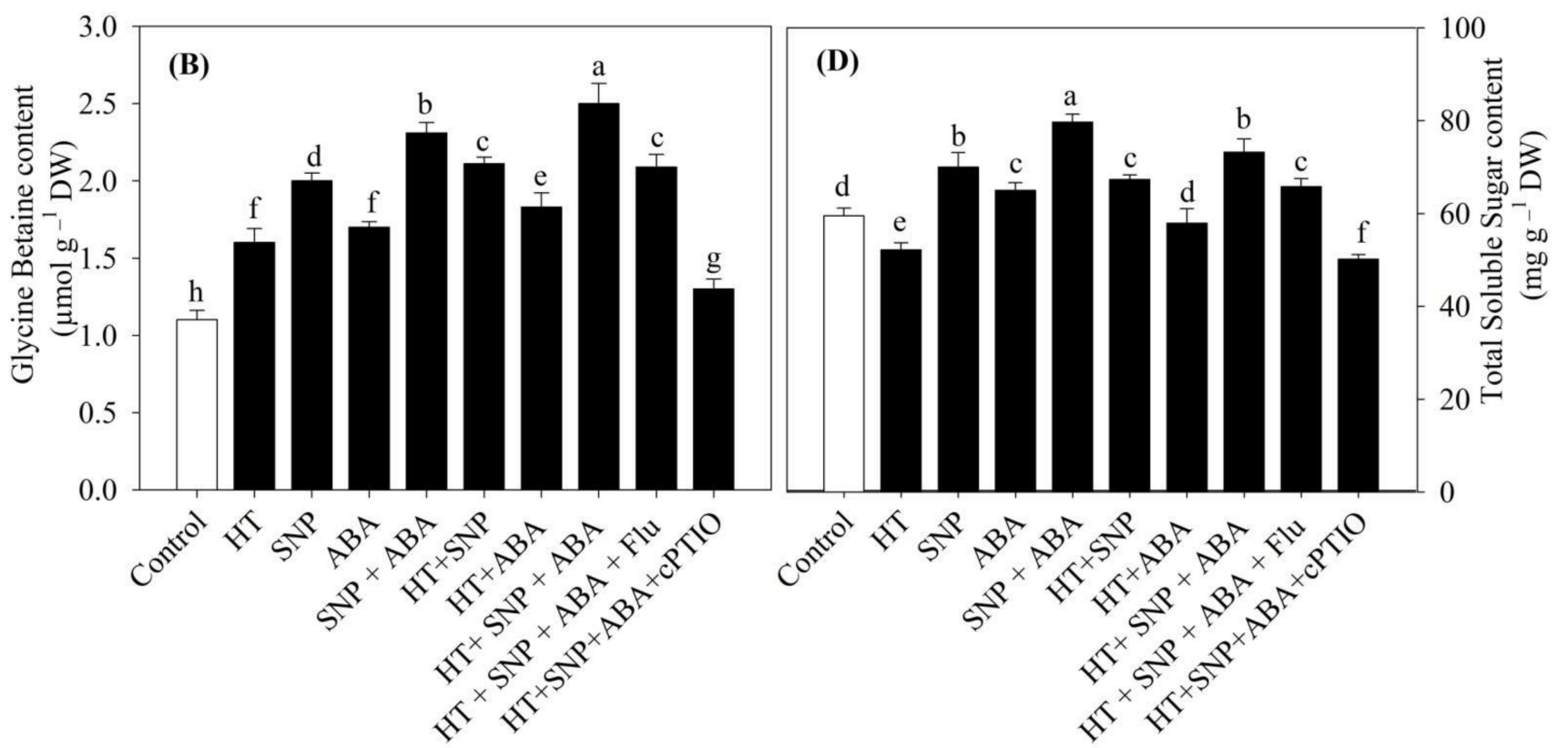

Figure 4. (A) Proline, (B) glycine betaine, (C) trehalose, and (D) total soluble sugar of wheat (Triticum aestivum L. var. WH 542) leaves treated with $100 \mu \mathrm{M} \mathrm{SNP}$ and/or ABA in the presence $\left(40{ }^{\circ} \mathrm{C}\right)$ or absence $\left(25^{\circ} \mathrm{C}\right)$ of heat stress at 30 days after sowing (DAS). The combined NO and ABA treatment under heat stress was also subjected to $100 \mu \mathrm{M}$ cPTIO and/or $80 \mu \mathrm{M}$ fluridone at 30 DAS. Data are presented as the treatment mean \pm SE $(n=4)$. Data followed by the same letter are not significantly different by Tukey test at $p<0.05$. ABA, abscisic acid; cPTIO, 2-4-carboxyphenyl-4,4,5,5tetramethylimidazoline-1-oxyl-3-oxide; Flu, fluridone; HT, heat stress; SNP, sodium nitroprusside.
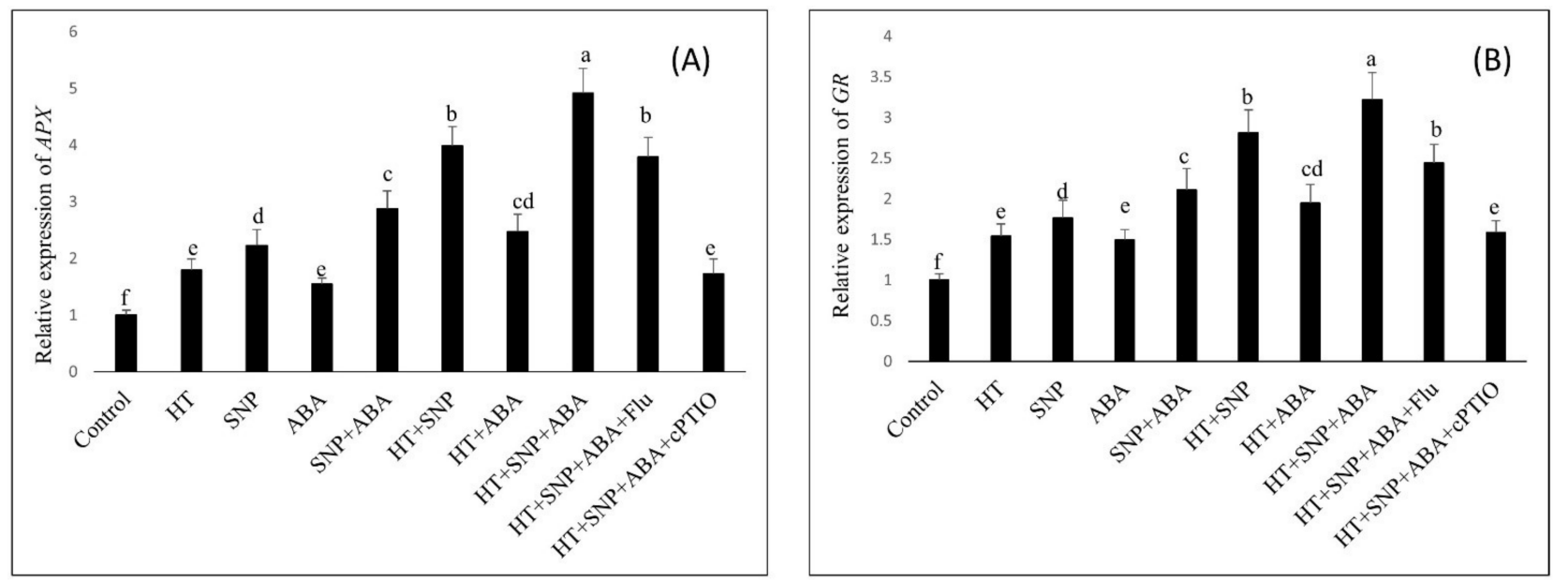

Figure 5. Relative expression of the genes (A) APX and (B) GR of wheat (Triticum aestivum L. var. WH 542) leaves treated with $100 \mu \mathrm{M} \mathrm{SNP}$ and/or ABA in the presence $\left(40^{\circ} \mathrm{C}\right)$ or absence $\left(25^{\circ} \mathrm{C}\right)$ of heat stress at 30 days after sowing (DAS). The combined NO and ABA treatment under heat stress was also subjected to $100 \mu \mathrm{M}$ cPTIO and/or $80 \mu \mathrm{M}$ fluridone (Flu) at 30 DAS. Results are represented relative to the total of the respective control (control, 1$)$. Data are presented as the mean $\pm \mathrm{SE}(n=4)$. Data followed by the same letter are not significantly different by Tukey test at $p<0.05$.ABA, abscisic acid; cPTIO, 2-4-carboxyphenyl-4,4,5,5- tetramethylimidazoline-1-oxyl-3-oxide; Flu, fluridone; HT, heat stress; SNP, sodium nitroprusside.

\section{Discussion}

Increased temperatures, above what is required for plant growth, significantly reduces photosynthesis and impedes growth and yield [1,89,90]. According to the IPCC [5], global warming of $1.5^{\circ} \mathrm{C}$ and $2{ }^{\circ} \mathrm{C}$ will be exceeded during the 21 st century unless emission of 
greenhouse gases is controlled. Plants exposed to heat stress exhibit overproduction of ROS that cause lipid per-oxidation, DNA damage, protein oxidation, and cell apoptosis [91-95]. However, these ROS function as a signaling molecule that confers plants to acclimate and adapt to abiotic stresses [96]. One such mechanism of adaptation is the activation of antioxidative enzymes in the plants exposed to stress. However, the efficiency of these antioxidants is not enough to reduce oxidative stress; therefore, we need to gain knowledge on mechanisms that can boost antioxidative metabolism. Furthermore, osmolytes are the other crucial components that maintain the cell redox state by functioning as an antioxidant on the one hand and maintaining osmotic balance on the other. ROS suppression could also be achieved through phytohormones, which activate signals for antioxidant defense and osmolytes accumulation.

Nitric oxide and ABA are essential regulators for plants defense against stress. Iqbal et al. [49] reviewed the interaction between ABA and NO for heat tolerance and explored various common mechanisms in their interaction. In the present work, we have studied the effect of $\mathrm{NO}$ and ABA in alleviating heat stress individually and in combination, also studied how they regulate each other through the use of NO and ABA inhibitors. Nitric oxide is a gaseous signaling molecule that functions as a signaling molecule at low concentrations, whereas it causes nitro-oxidative stress at higher concentrations, causing cellular damage. Nitric oxide and ABA increase the antioxidant capacity under high temperature stress [56,97], suppress ROS, and maintain cellular redox homeostasis. The role of these hormones in regulating osmolytes has also been investigated [57,98,99]. We observed that both NO and ABA help in heat tolerance, and the ABA effect was depended on NO. However, when applied simultaneously, we observed maximum heat stress alleviation.

\subsection{Role of $N O$ and $A B A$ in Reducing Photosynthesis Inhibition and Growth under Heat Stress}

Heat stress adversely affects the photosynthesis and growth of plants $[12,13,70]$ by affecting the thylakoid membrane, chloroplast protein complexes, photosystem II, and activity of Rubisco $[13,100]$. In order to protect plants from heat stress, the photosynthetic efficiency of plants should be improved. Nitric oxide prevents chlorophyll loss and protects activity of PSII and photosynthesis under stress [12,101,102]. Treatment with SNP was found to maintain the $\mathrm{Fv} / \mathrm{Fm}$ level while inhibiting $\mathrm{F}_{0}$ rise, and increased chlorophyll and Rubisco by overexpressing NOA1 in rice [103]. The effect of NO in photosynthetic protection is concentration dependent; at a high concentration, it causes damage to the photosynthetic machinery in response to high temperature [70]. Similarly, a high NO concentration was found in the present study under heat stress. However, NO whensupplied exogenously under heat stress signaled for the reduction in oxidative stress through the increase in the antioxidant enzymes, which subsequently caused lower NO generation. Excess NO in Pisum sativum reduced photosynthesis probably by reversibly binding to the thylakoid membrane complex and restricting electron transport [104].

Nitric oxide crosstalk with plant abiotic-stress responses and stress regulators exists. In this study, its crosstalk with $\mathrm{ABA}$ has been discussed. It has been shown that $\mathrm{ABA}$ responsive-element binding protein 9 (ABP9) improves photosynthesis under heat stress in Arabidopsis [105]. Increased production of ABA under heat stress increases activity of antioxidant enzymes and helps maintain plants' water status through the regulation of stomata $[56,106]$. We observed that ABA supplementation under heat stress resulted in increased production of $\mathrm{H}_{2} \mathrm{O}_{2}$, leading to an increase in antioxidants to adjust to heat stress. The decrease in photosynthesis under heat stress in plants supplemented with ABA in comparison to the control could probably be due to increased $\mathrm{H}_{2} \mathrm{O}_{2}$ and partial stomatal closure supported by reduced stomatal conductance and intercellular $\mathrm{CO}_{2}$ concentration. The combined NO with ABA maximally increased the activity and expression of antioxidant enzymes and osmolytes production to scavenge ROS efficiently and improve photosynthesis above the control. It may be emphasized that $\mathrm{NO}$ with ABA restricted the ABA-mediated increase in $\mathrm{H}_{2} \mathrm{O}_{2}$ content. The effect of ABA on photosynthesis was found to be dependent on NO because inhibition of $\mathrm{NO}$ by cPTIO inhibited the observed increase 
in photosynthesis by ABA. This is also indicative of NO signaling downstream of ABA, while ABA inhibition had little effect on NO action. A study by Wang et al. [107] suggested that ABA signaling results in NO formation, which causes $S$-nitrosylation of $S n R K 2.6$ at a cysteine residue close to the kinase catalytic site and blocks the kinase activity resulting in ABA insensitivity in stomatal regulation.

Similar to the increase in photosynthetic trait, there was an increase in leaf area and plant dry mass with both NO, ABA, and their combination under heat stress. An increase in growth was observed in Oryza sativa plants when $\mathrm{NO}$ was applied exogenously at low concentrations and alleviated salt or heat stress [108]. In the callus of Phragmites communis, $0.2 \mathrm{mM}$ SNP and S-nitrose-N-acetyl penicillamine reduced the adversities of heat and protected a reduction in growth and cell viability [27]. ABA also protects plant growth under stress and ABA signaling mutant abi-1 exhibited increased TBARS content and reduced the survival rate under heat stress together with a reduction in fresh weight and plant diameter in response to heat stress [109]. However, the reports on NO and ABA interaction under heat stress are scanty. We have reported that when ABA-treated plants are supplied with NO, synergy in their action mediates the maximum increase in antioxidants and osmolytes to protect plants from the adversities of heat stress on photosynthesis.

4.2. Nitric Oxide and ABA Increased Osmolytes Accumulation and Antioxidant Enzyme Activity and Expression to Reduce Heat-Induced Oxidative Stress

In the present study, the decrease in oxidative stress was due to enhanced activity of the antioxidative enzymes SOD, CAT, APX, GR, and APX and GR gene expression. A similar decrease in $\mathrm{H}_{2} \mathrm{O}_{2}$ content and increase in antioxidant enzymes with ABA application under heat stress has been reported [110]. It has been shown that both $\mathrm{ABA}$ and $\mathrm{H}_{2} \mathrm{O}_{2}$ increased $\mathrm{NO}$ generation in mesophyll cells of maize leaves, and $\mathrm{H}_{2} \mathrm{O}_{2}$ was required for the ABA-induced NO generation [111]. In the present study also, ABA function was dependent on $\mathrm{NO}$ since inhibition of $\mathrm{NO}$ by $\mathrm{NO}$ scavenger substantially reduced the production of ABA-induced $\mathrm{NO}$ and activities of several antioxidant enzymes that were induced with ABA. In Stylosanthes guianensis, ABA-mediated NO generation was responsible for the increase in antioxidant enzymes; however, blocking the NO generation by specific inhibitors reduced the ABA-induced activity of antioxidants under heat stress [78].

The ameliorative effect of NO with ABA was also because of the increase in osmolytes accumulation. We studied the content of proline, GB, trehalose, and total soluble sugar in heat-stressed plants and found their content increased under heat stress, except for total soluble sugars, for which the content decreased. Application of either NO or ABA increased the content of all these osmolytes but maximally when they were applied in combination. Osmotic adjustment helps protect the cells against abiotic stresses, and it has an important role in regulating membrane fluidity and scavenging ROS. Proline, an osmoprotectant, protected Vicia faba under heat stress, and the increase in proline increased with an increase in NO [94]. Nitric oxide helped in mitigating oxidative stress by maintaining cellular redox homoeostasis by neutralizing ROS under heat stress [2]. Sharma et al. [112] reviewed phytohormonal regulation of osmolytes accumulation under different abiotic stress conditions. Under salt stress in wheat seedlings, NO increased the synthesis of endogenous ABA and acted downstream of ABA in ABA-induced proline accumulation [61]. Applying exogenous ABA to plants under drought stress significantly enhanced the sugar accumulation but decreased the starch content in leaves [113]. Its application increased the levels of sugar and related key enzymes to improve cold tolerance in winter wheat [114]. It was found that ABA enhanced sugar accumulation under saline conditions [115] and ABA and sucrose increased the survival rate of bromegrass cells under heat stress [116]. It has been reported that genotypes that maintain a higher accumulation of proline, GB, and expression of heat shock proteins, together with activity of antioxidant enzymes such as catalase, peroxidase, SOD, and GR, can tolerate high temperature efficiently through sustaining cellular physiology [117]. Nitric oxide also influences soluble sugar accumulation under heat stress. Supplementation of NO to heat-stressed plants reduced the stress-induced 
glucose accumulation by increasing its utilization for growth [70]. Exogenous $\mathrm{NO}$ with $\mathrm{Ca}^{2+}$ alleviated oxidative stress caused by high temperature through enhancement in osmolyte accumulation, antioxidants, and nitrate reductase (NR) activity [118]. In tomato, SNP supplementation reduced oxidative stress via increased synthesis of compatible solutes and antioxidative enzymes together with increased activity of Rubisco, NR activity, total structural carbohydrate, and photosynthetic pigments in tomato [60]. The role of GB in heat tolerance is advocated by various studies $[119,120]$. ABA was found to affect GB by regulating the activity of $\mathrm{BADH}$ via modulating the phosphorylation process of important receptors such as SnRK2 [121]. In chickpea, ABA was found to increase GB and proline together with trehalose content to impart heat tolerance [59]. Similarly, SNP increased GB and proline content in S. lycopersicum seedlings for heat stress mitigation together with $\mathrm{Ca}^{2+}[60]$. GB content was found to increase with a NO donor, while a NO inhibitor blocked its formation, supporting the role of NO in GB formation [122]. Trehalose is a non-reducing disaccharide, which accumulated in Arabidopsis plants under heat stress [123] and acted as a ROS scavenger in heat-stressed wheat plants [124]. Trehalose regulates water-use efficiency and stomatal movement in most plants and is vital for sustaining growth under stressful situation [125]. Li et al. [64] have reported that trehalose helps in the stabilization of dehydrated enzymes, proteins, and membrane lipids and protects biological structures from damage because of its function as an osmoprotectant during desiccation. Trehalose accumulation increased in the present study under heat stress and further with both ABA and NO application. Trehalose accumulation increased with NO in P. eryngii var. tuoliensis under heat stress [126]. Osmoprotectants such as proline, GB, and trehalose increase under heat stress and function as stress signaling molecules to protect denaturation of enzymes, membrane stabilization, and protection of photosynthetic pigments, this through their role as antioxidants to scavenge deleterious ROS and as osmolytes to maintain osmotic homeostasis $[127,128]$. The increase in these osmolytes in our present study is also indicative of the increase in tolerance potential of wheat with $\mathrm{NO}$ and $\mathrm{ABA}$ under heat stress.

\subsection{The Interaction of $N O$ and $A B A$ and Their Production}

The literature has shown an increase in $\mathrm{NO}$ and $\mathrm{ABA}$ content in various plant species against high-temperature treatments [31,106]. Nitric oxide-mediated regulation of ABA biosynthesis for water stress was reported by Xing et al. [129]. In the present study, NO supplementation decreased the NO content even under heat stress. Such a decrease has also been reported earlier by Iqbal et al. [70]. It also decreases the ABA content compared to heat treatment. The reduction in ABA was optimum in NO and ABA combined treatment, which maximally alleviated stress. Reports are suggestive of NO and ABA interaction, and it has recently been reviewed [49]. Zhang et al. [130] reported increased NO formation in transgenic tobacco over-expressing SgNCED1 together with increased contents of ABA, $\mathrm{H}_{2} \mathrm{O}_{2}$, and activities of antioxidant enzyme to impart drought and salt stress tolerance. They reported that $\mathrm{NO}$ acts as a downstream signaling element in the ABA signaling pathway, and a reduction in $\mathrm{NO}$ production or its scavenging decreases or, in some cases, even eliminates ABA responses. However, ABA inhibition caused no effect on exogenous NOmediated responses. In contrast, $\mathrm{NO}$ was not always required during the ABA signaling cascades as during stomatal closure [131] or light-induced stomatal opening inhibition [132]. The regulation of antioxidant enzymes maintains adjustment of the proper NO/ROS balance by S-nitrosylation $[133,134]$, and this is an absolute requirement for stress-induced ROS. Heat stress increased the content of both NO and ABA; however, their exogenous application lowered the heat stress and also their content. Further, since ABA has been reported to increase the $\mathrm{H}_{2} \mathrm{O}_{2}$ content and consequently antioxidant activity, the $\mathrm{H}_{2} \mathrm{O}_{2}$ content was comparatively higher with ABA treatment compared to NO treatment.

\section{Conclusions}

It may be concluded that $\mathrm{NO}$ and $\mathrm{ABA}$ reduced the heat stress impacts on photosynthesis and growth, independently and maximally, with their combined application through 
regulation of activity and expression of antioxidant enzymes and osmolytes accumulation. The greatest benefit was obtained with the combined application of NO and ABA. However, $\mathrm{NO}$ was better than ABA through a maximum increase in activity of antioxidant enzymes and osmolytes accumulation. The response of plants to ABA was NO dependent. The inhibition of NO significantly reduced the production of ABA-induced NO and activity of antioxidant enzymes that were induced with ABA. The adaptation of plants against heat stress by ABA can be enhanced by the addition of NO.

Supplementary Materials: The following supporting information can be downloaded at: https:/ / www.mdpi.com/article/10.3390/antiox11020372/s1, Details of the Material and Methods are provided in the Supplementary Files; Table S1: Primer pairs used for quantitative RT-PCR.

Author Contributions: Conceptualization, N.I., S.U. and N.A.K.; methodology, N.I. and Z.S.; software, A.S.; formal analysis, M.F.; investigation, N.A.K.; resources, N.I.; data curation, N.I., Z.S. and M.F.; writing-original draft preparation, N.I.; writing—review and editing, N.I., S.U. and N.A.K.; visualization, N.I.; supervision, S.U. and N.A.K.; funding acquisition, A.S. All authors have read and agreed to the published version of the manuscript.

Funding: This research received no external funding.

Institutional Review Board Statement: Not applicable.

Informed Consent Statement: Not applicable.

Data Availability Statement: Data are contained within the article and Supplementary Materials.

Acknowledgments: The first author is thankful to DST-SERB NPDF (PDF/2019/000770) for the post-doctoral fellowship.

Conflicts of Interest: The authors declare no conflict of interest.

\section{References}

1. Wahid, A.; Gelani, S.; Ashraf, M.; Foolad, M.R. Heat tolerance in plants: An overview. Environ. Exp. Bot. 2007, 61, 199-223. [CrossRef]

2. Parankusam, S.; Adimulam, S.S.; Bhatnagar-Mathur, P.; Sharma, K.K. Nitric oxide (NO) in plant heat stress tolerance: Current knowledge and perspectives. Front. Plant Sci. 2017, 8, 1582. [CrossRef]

3. Anderson, R.; Bayer, P.E.; Edwards, D. Climate change and the need for agricultural adaptation. Curr. Opin. Plant Biol. 2020, 56, 197-202. [CrossRef]

4. Johkan, M.; Oda, M.; Maruo, T.; Shinohara, Y. Crop production and global warming. In Global Warming Impacts-Case Studies on the Economy, Human Health, and on Urban and Natural Environments; Stefano, C., Ed.; InTech: Rijeka, Croatia, 2011 ; pp. $139-152$.

5. IPCC. The Climate Change 2021: The Physical Science Basis. In Contribution of Working Group I to the Sixth Assessment Report of the Intergovernmental Panel on Climate Change; Cambridge University Press: New York, NY, USA, 2021.

6. Teixeira, E.I.; Fischer, G.; Van Velthuizen, H.; Walter, C.; Ewert, F. Global hot-spots of heat stress on agricultural crops due to climate change. Agric. For. Meteorol. 2013, 170, 206-215. [CrossRef]

7. Deryng, D.; Conway, D.; Ramankutty, N.; Price, J.; Warren, R. Global crop yield response to extreme heat stress under multiple climate change futures. Environ. Res. Lett. 2014, 9, 034011. [CrossRef]

8. Wahid, A. Physiological implications of metabolite biosynthesis for net assimilation and heat-stress tolerance of sugarcane (Saccharum officinarum) sprouts. J. Plant Res. 2007, 120, 219-228. [CrossRef] [PubMed]

9. Mathur, S.; Allakhverdiev, S.I.; Jajoo, A. Analysis of high temperature stress on the dynamics of antenna size and reducing side heterogeneity of Photosystem II in wheat leaves (Triticum aestivum). Biochim. Biophys. Acta 2011, 1807, 22-29. [CrossRef]

10. Khan, M.I.R.; Asgher, M.; Khan, N.A. Rising temperature in the changing environment: A serious threat to plants. Clim. Chang. Environ. Sustain. 2013, 1, 25-36. [CrossRef]

11. Brestic, M.; Zivcak, M.; Kunderlikova, K.; Allakhverdiev, S.I. High temperature specifically affects the photoprotective responses of chlorophyll b-deficient wheat mutant lines. Photosynth. Res. 2016, 130, 251-266. [CrossRef]

12. Gautam, H.; Sehar, Z.; Rehman, M.T.; Hussain, A.; AlAjmi, M.F.; Khan, N.A. Nitric oxide enhances photosynthetic nitrogen and sulfur-use efficiency and activity of ascorbate-glutathione cycle to reduce high temperature stress-induced oxidative stress in rice (Oryza sativa L.) plants. Biomolecules 2021, 11, 305. [CrossRef]

13. Gautam, H.; Fatma, M.; Sehar, Z.; Iqbal, N.; Albaqami, M.; Khan, N.A. Exogenously-sourced ethylene positively modulates photosynthesis, carbohydrate metabolism, and antioxidant defense to enhance heat tolerance in rice. Int. J. Mol. Sci. 2022, 23, 1031. [CrossRef] 
14. Suzuki, N.; Mittler, R. Reactive oxygen species and temperature stresses: A delicate balance between signaling and destruction. Physiol. Plant. 2006, 126, 45-51. [CrossRef]

15. Awasthi, R.; Bhandari, K.; Nayyar, H. Temperature stress and redox homeostasis in agricultural crops. Front. Environ. Sci. 2015, 3, 11. [CrossRef]

16. Prasad, A.; Ferretti, U.; Sedlářová, M.; Pospíšil, P. Singlet oxygen production in Chlamydomonas reinhardtii under heat stress. Sci. Rep. 2016, 6, 20094. [CrossRef] [PubMed]

17. Smertenko, A.; Dráber, P.; Viklický, V.; Opatrný, Z. Heat stress affects the organization of microtubules and cell division in Nicotiana tabacum cells. Plant Cell Environ. 1997, 20, 1534-1542. [CrossRef]

18. Hu, S.; Ding, Y.; Zhu, C. Sensitivity and responses of chloroplasts to heat stress in plants. Front. Plant Sci. 2020, 11, 375. [CrossRef]

19. Brestic, M.; Zivcak, M.; Kalaji, H.M.; Carpentier, R.; Allakhverdiev, S.I. Photosystem II thermostability in situ: Environmentally induced acclimation and genotype-specific reactions in Triticum aestivum L. Plant Physiol. Biochem. 2012, 57,93-105. [CrossRef] [PubMed]

20. Yamori, W.; Hikosaka, K.; Way, D.A. Temperature response of photosynthesis in $\mathrm{C}_{3}, \mathrm{C}_{4}$, and CAM plants: Temperature acclimation and temperature adaptation. Photosynth. Res. 2014, 119, 101-117. [CrossRef] [PubMed]

21. Devasirvatham, V.; Gaur, P.M.; Mallikarjuna, N.; Tokachichu, R.N.; Trethowan, R.M.; Tan, D.K. Effect of high temperature on the reproductive development of chickpea genotypes under controlled environments. Funct. Plant Biol. 2012, 39, 1009-1018. [CrossRef]

22. Hasanuzzaman, M.; Nahar, K.; Alam, M.; Roychowdhury, R.; Fujita, M. Physiological, biochemical, and molecular mechanisms of heat stress tolerance in plants. Int. J. Mol. Sci. 2013, 14, 9643-9684. [CrossRef]

23. Sharma, N.; Yadav, A.; Khetarpal, S.; Anand, A.; Sathee, L.; Kumar, R.R.; Singh, B.; Soora, N.K.; Pushkar, S. High day-night transition temperature alters nocturnal starch metabolism in rice (Oryza sativa L.). Acta Physiol. Plant 2017, 39, 74. [CrossRef]

24. Hossain, M.A.; Fujita, M. Hydrogen peroxide priming stimulates drought tolerance in mustard (Brassica juncea L.) seedlings. Plant Gene Trait 2013, 4, 109-123.

25. Nahar, K.; Hasanuzzaman, M.; Alam, M.M.; Fujita, M. Exogenous glutathione confers high temperature stress tolerance in mung bean (Vigna radiata L.) by modulating antioxidant defense and methylglyoxal detoxification system. Environ. Exp. Bot. 2015, 112, 44-54. [CrossRef]

26. Savvides, A.; Ali, S.; Tester, M.; Fotopoulos, V. Chemical priming of plants against multiple abiotic stresses: Mission possible? Trends Plant Sci. 2016, 21, 329-340. [CrossRef] [PubMed]

27. Song, L.; Ding, W.; Zhao, M.; Sun, B.; Zhang, L. Nitric oxide protects against oxidative stress under heat stress in the calluses from two ecotypes of reed. Plant Sci. 2006, 171, 449-458. [CrossRef]

28. Khan, M.I.R.; Iqbal, N.; Masood, A.; Per, T.S.; Khan, N.A. Salicylic acid alleviates adverse effects of heat stress on photosynthesis through changes in proline production and ethylene formation. Plant Signal. Behav. 2013, 8, e26374. [CrossRef] [PubMed]

29. Mostofa, M.G.; Yoshida, N.; Fujita, M. Spermidine pretreatment enhances heat tolerance in rice seedlings through modulating antioxidative and glyoxalase systems. Plant Growth Regul. 2014, 73, 31-44. [CrossRef]

30. Chan, Z.; Shi, H. Improved abiotic stress tolerance of bermudagrass by exogenous small molecules. Plant Signal. Behav. 2015, 10, e991577. [CrossRef]

31. Domingos, P.; Prado, A.M.; Wong, A.; Gehring, C.; Feijo, J.A. Nitric oxide: A multitasked signaling gas in plants. Mol. Plant. 2015, 8, 506-520. [CrossRef]

32. Yu, M.; Lamattina, L.; Spoel, S.H.; Loake, G.J. Nitric oxide function in plant biology: A redox cue in deconvolution. New Phytol. 2014, 202, 1142-1156. [CrossRef]

33. Bethke, P.C.; Libourel, I.G.; Jones, R.L. Nitric oxide in Seed Dormancy and Germination. In Annual Plant Reviews, Seed Development, Dormancy and Germination; Bradford, K.J., Nonogaki, H., Eds.; John Wiley \& Sons: Hoboken, NJ, USA, 2007; Volume 27, pp. 153-175.

34. Popova, L.; Tuan, T. Nitric oxide in plants: Properties, biosynthesis and physiological functions. Iran. J. Sci. Technol. 2010, 34, 173-183. [CrossRef]

35. Mishina, T.E.; Lamb, C.; Zeier, J. Expression of a nitric oxide degrading enzyme induces a senescence programme in Arabidopsis. Plant Cell Environ. 2007, 30, 39-52. [CrossRef] [PubMed]

36. Neill, S.; Barros, R.; Bright, J.; Desikan, R.; Hancock, J.; Harrison, J.; Morris, P.; Ribeiro, D.; Wilson, I. Nitric oxide, stomatal closure, and abiotic stress. J. Exp. Bot. 2008, 59, 165-176. [CrossRef] [PubMed]

37. Sehrawat, A.; Gupta, R.; Deswal, R. Nitric oxide-cold stress signalling cross-talk, evolution of a novel regulatory mechanism. Proteomics 2013, 13, 1816-1835. [CrossRef]

38. Pagnussat, G.C.; Simontacchi, M.; Puntarulo, S.; Lamattina, L. Nitric oxide is required for root organogenesis. Plant Physiol. 2002, 129, 954-956. [CrossRef] [PubMed]

39. Gould, K.S.; Lamotte, O.; Klinguer, A.; Pugin, A.; Wendehenne, D. Nitric oxide production in tobacco leaf cells: A generalized stress response? Plant Cell Environ. 2003, 26, 1851-1862. [CrossRef]

40. Asgher, M.; Per, T.S.; Masood, A.; Fatma, M.; Freschi, L.; Corpas, F.J.; Khan, N.A. Nitric oxide signaling and its crosstalk with other plant growth regulators in plant responses to abiotic stress. Environ. Sci. Pollut. Res. 2017, 24, 2273-2285. [CrossRef]

41. Sehar, Z.; Masood, A.; Khan, N.A. Nitric oxide reverses glucose-mediated photosynthetic repression in wheat (Triticum aestivum L.) under salt stress. Environ. Exp. Bot. 2019, 161, 277-289. [CrossRef] 
42. Diao, Q.N.; Song, Y.J.; Shi, D.M.; Qi, H.Y. Nitric oxide induced by polyamines involves antioxidant systems against chilling stress in tomato (Lycopersicon esculentum Mill) seedling. J. Zhejiang Univ. Sci. B 2016, 17, 916-930. [CrossRef]

43. Gayatri, G.; Agurla, S.; Raghavendra, A. Nitric oxide in guard cells as an important secondary messenger during stomatal closure. Front. Plant Sci. 2013, 4, 425. [CrossRef]

44. Bartels, D.; Sunkar, R. Drought and salt tolerance in plants. Crit. Rev. Plant Sci. 2005, 24, 23-58. [CrossRef]

45. Finkelstein, R. Abscisic acid synthesis and response. Arab. Book/Am. Soc. Plant Biol. 2013, 11, e0166. [CrossRef] [PubMed]

46. Teplova, I.R.; Farkhutdinov, R.G.; Mitrichenko, A.N.; Ivanov, I.I.; Veselov, S.Y.; Valcke, R.L.; Kudoyarova, G.R. Response of tobacco plants transformed with the ipt gene to elevated temperature. Russ. J. Plant Physiol. 2000, 47, 367-369.

47. Gong, M.; Li, Y.J.; Chen, S.Z. Abscisic acid-induced thermotolerance in maize seedlings is mediated by calcium and associated with antioxidant systems. J. Plant Physiol. 1998, 153, 488-496. [CrossRef]

48. Dai, X.; Wang, Y.; Chen, Y.; Li, H.; Xu, S.; Yang, T.; Zhang, X.; Su, X.; Xia, Z. Overexpression of NtDOG1L-T improves heat stress tolerance by modulation of antioxidant capability and defense-, heat-, and ABA-related gene expression in tobacco. Front. Plant Sci. 2020, 11, 568489. [CrossRef]

49. Iqbal, N.; Umar, S.; Khan, N.A.; Corpas, F.J. Crosstalk between abscisic acid and nitric oxide under heat stress: Exploring new vantage points. Plant Cell Rep. 2021, 40, 1429-1450. [CrossRef]

50. Groß, F.; Durner, J.; Gaupels, F. Nitric oxide, antioxidants and prooxidants in plant defence responses. Front. Plant Sci. 2013, 4, 419. [CrossRef]

51. Alnusairi, G.S.; Mazrou, Y.S.; Qari, S.H.; Elkelish, A.A.; Soliman, M.H.; Eweis, M.; Abdelaal, K.; El-Samad, G.A.; Ibrahim, M.F.; El Nahhas, N. Exogenous nitric oxide reinforces photosynthetic efficiency, osmolyte, mineral uptake, antioxidant, expression of stress-responsive genes and ameliorates the effects of salinity stress in wheat. Plants 2021, 10, 1693. [CrossRef]

52. He, H.; Oo, T.L.; Huang, W.; He, L.F.; Gu, M. Nitric oxide acts as an antioxidant and inhibits programmed cell death induced by aluminum in the root tips of peanut (Arachis hypogaea L.). Sci. Rep. 2019, 9, 9516. [CrossRef]

53. Ahmad, P.; Abdel, L.A.A.; Hashem, A.; Abd_Allah, E.F.; Gucel, S.; Tran, L.S.P. Nitric oxide mitigates salt stress by regulating levels of osmolytes and antioxidant enzymes in chickpea. Front. Plant Sci. 2016, 7, 347. [CrossRef]

54. Guan, L.M.; Zhao, J.; Scandalios, J.G. Cis-elements and trans-factors that regulate expression of the maize Cat1 antioxidant gene in response to $\mathrm{ABA}$ and osmotic stress: $\mathrm{H}_{2} \mathrm{O}_{2}$ is the likely intermediary signaling molecule for the response. Plant J. 2000, 22, 87-95. [CrossRef] [PubMed]

55. Zhang, H.; Liu, Y.; Wen, F.; Yao, D.; Wang, L.; Guo, J.; Ni, L.; Zhang, A.; Tan, M.; Jiang, M. A novel rice $\mathrm{C}_{2} \mathrm{H}_{2}$-type zinc finger protein, ZFP36, is a key player involved in abscisic acid-induced antioxidant defence and oxidative stress tolerance in rice. J. Exp. Bot. 2014, 65, 5795-5809. [CrossRef] [PubMed]

56. Hu, X.; Li, Y.; Li, C.; Yang, H.; Wang, W.; Lu, M. Characterization of small heat shock proteins associated with maize tolerance to combined drought and heat stress. J. Plant Growth Regul. 2010, 29, 455-464. [CrossRef]

57. Strizhov, N.; Abrahám, E.; Okrész, L.; Blickling, S.; Zilberstein, A.; Schell, J.; Koncz, C.; Szabados, L. Differential expression of two P5CS genes controlling proline accumulation during salt-stress requires ABA and is regulated by ABA1, ABI1 and AXR2 in Arabidopsis. Plant J. 1997, 12, 557-569.

58. Sripinyowanich, S.; Klomsakul, P.; Boonburapong, B.; Bangyeekhun, T.; Asami, T.; Gu, H.; Buaboocha, T.; Chadchawan, S. Exogenous ABA induces salt tolerance in indica rice (Oryza sativa L.): The role of OsP5CS1 and OsP5CR gene expression during salt stress. Environ. Exp. Bot. 2013, 86, 94-105. [CrossRef]

59. Kumar, S.; Kaushal, N.; Harsh, N.; Gaur, P.M. Abscisic acid induces heat tolerance in chickpea (Cicer arietinum L.) seedlings by facilitated accumulation of osmoprotectants. Acta Physiol. Plant. 2012, 34, 1651-1658. [CrossRef]

60. Siddiqui, M.H.; Alamri, S.; Al-Khaishany, M.Y.Y.; Al-Qutami, M.A.; Ali, H.M.; Khan, M.N. Nitric oxide and calcium induced physio-biochemical changes in tomato (Solanum lycopersicum) plant under heat stress. Fresenius Environ. Bull. 2017, 26, 1663-1672.

61. Hai-Hua, R.; Wen-Biao, S.; Lang-Lai, X. Nitric oxide involved in the abscisic acid induced proline accumulation in wheat seedling leaves under salt stress. Acta Bot. Sin. 2004, 46, 1307-1315.

62. Fan, H.F.; Du, C.X.; Guo, S.R. Effect of nitric oxide on proline metabolism in cucumber seedlings under salinity stress. J. Am. Soc. Hort. Sci. 2012, 137, 127-133. [CrossRef]

63. Tan, J.; Zhao, H.; Hong, J.; Han, Y.; Li, H.; Zhao, W. Effects of exogenous nitric oxide on photosynthesis, antioxidant capacity and proline accumulation in wheat seedlings subjected to osmotic stress. World J. Agric. Sci. 2008, 4, 307-313.

64. Li, Z.G.; Luo, L.J.; Zhu, L.P. Involvement of trehalose in hydrogensulfide donor sodium hydrosulfide-induced the acquisition of heat tolerance in maize (Zea mays L.) seedlings. Bot. Stud. 2014, 55, 20. [CrossRef] [PubMed]

65. Shiferaw, B.; Smale, M.; Braun, H.J.; Duveiller, E.; Reynolds, M.; Muricho, G. Crops that feed the world 10. Past successes and future challenges to the role played by wheat in global food security. Food Secur. 2013, 5, 291-317. [CrossRef]

66. FAO. FAOSTAT; Food and Agriculture Organization of the United Nations: Rome, Italy, 2021.

67. Jaradat, A.A. Ecogeography, genetic diversity and breeding value of wild emmer wheat (Triticum dicoccoides Körn ex Asch. \& Graebn). Thell.Austr. J. Crop. Sci. 2011, 5, 1072-1086.

68. Poudel, P.B.; Poudel, M.R. Heat stress effects and tolerance in wheat: A review. J. Biol. Todays World 2020, 9, 217.

69. Fatma, M.; Iqbal, N.; Sehar, Z.; Alyemeni, M.N.; Kaushik, P.; Khan, N.A.; Ahmad, P. Methyl jasmonate protects the PS II system by maintaining the stability of chloroplast D1 protein and accelerating enzymatic antioxidants in heat-stressed wheat plants. Antioxidants 2021, 10, 1216. [CrossRef] [PubMed] 
70. Iqbal, N.; Umar, S.; Khan, N.A.; Corpas, F.J. Nitric oxide and hydrogen sulfide coordinately reduce glucose sensitivity and decrease oxidative stress via ascorbate-glutathione cycle in heat-stressed wheat (Triticum aestivum L.) plants. Antioxidants 2021, 10, 108. [CrossRef]

71. Asseng, S.; Ewert, F.; Martre, P.; Rötter, R.P.; Lobell, D.B.; Cammarano, D.; Kimball, B.A.; Ottman, M.J.; Wall, G.W.; White, J.W.; et al. Rising temperatures reduce global wheat production. Nat. Clim. Chang. 2015, 5, 143-147. [CrossRef]

72. Wu, S.; Hu, C.; Tan, Q.; Zhao, X.; Xu, S.; Xia, Y.; Sun, X. Nitric oxide acts downstream of abscisic acid in molybdenum-induced oxidative tolerance in wheat. Plant Cell Rep. 2018, 37, 599-610. [CrossRef] [PubMed]

73. Usuda, H. The activation state of ribulose 1,5-bisphosphate carboxylase in maize leaves in dark and light. Plant Cell Physiol. 1985, 26, 1455-1463. [CrossRef]

74. Okuda, T.; Matsuda, Y.; Yamanaka, A.; Sagisaka, S. Abrupt increase in the level of hydrogen peroxide in leaves of winter wheat is caused by cold treatment. Plant Physiol. 1991, 97, 1265-1267. [CrossRef]

75. Dhindsa, R.S.; Plumb-Dhindsa, P.A.M.E.L.A.; Thorpe, T.A. Leaf senescence: Correlated with increased levels of membrane permeability and lipid peroxidation, and decreased levels of superoxide dismutase and catalase. J. Exp. Bot. 1981, 32, 93-101. [CrossRef]

76. Hung, K.T.; Kao, C.H. Nitric oxide counteracts the senescence of rice leaves induced by abscisic acid. J. Plant Physiol. 2003, 160, 871-879. [CrossRef] [PubMed]

77. Fatma, M.; Iqbal, N.; Gautam, H.; Sehar, Z.; Sofo, A.; D'Ippolito, I.; Khan, N.A. Ethylene and sulfur coordinately modulate the antioxidant system and ABA accumulation in mustard plants under salt stress. Plants 2021, 10, 180. [CrossRef] [PubMed]

78. Zhou, B.; Guo, Z.; Xing, J.; Huang, B. Nitric oxide is involved in abscisic acid-induced antioxidant activities in Stylosanthesguianensis. J. Exp. Bot. 2005, 56, 3223-3228. [CrossRef]

79. Bradford, M.M. A rapid and sensitive method for the quantitation of microgram quantities of protein utilizing the principle of protein-dye binding. Anal. Biochem. 1976, 72, 248-254. [CrossRef]

80. Beyer, W.F., Jr.; Fridovich, I. Assaying for superoxide dismutase activity: Some large consequences of minor changes in conditions Anal. Biochem. 1987, 161, 559-566. [CrossRef]

81. Giannopolitis, C.N.; Ries, S.K. Superoxide dismutases: I. Occurrence in higher plants. Plant Physiol. 1977, 59, 309-314. [CrossRef]

82. Aebi, H. Catalase in vitro. Methods Enzymol. 1984, 105, 121-126.

83. Nakano, Y.; Asada, K. Hydrogen peroxide is scavenged by ascorbate-specific peroxidase in spinach chloroplasts. Plant Cell Physiol. 1981, 22, 867-880. [CrossRef]

84. Foyer, C.H.; Halliwell, B. The presence of glutathione and glutathione reductase in chloroplasts: A proposed role in ascorbic acid metabolism. Planta 1976, 133, 21-25. [CrossRef]

85. Bates, L.S.; Waldren, R.P.; Teare, I.D. Rapid determination of free proline for water-stress studies. Plant Soil 1973, 39, 205-207. [CrossRef]

86. Grieve, C.M.; Grattan, S.R. Rapid assay for determination of water soluble quaternary ammonium compounds. Plant Soil 1983, 70, 303-307. [CrossRef]

87. Syeed, S.; Sehar, Z.; Masood, A.; Anjum, N.A.; Khan, N.A. Control of elevated ion accumulation, oxidative stress, and lipid peroxidation with salicylic acid-induced accumulation of glycine betaine in salinity-exposed Vigna radiata L. Appl. Biochem. Biotechnol. 2021, 193, 3301-3320. [CrossRef] [PubMed]

88. Xu, W.; Cui, K.; Xu, A.; Nie, L.; Huang, J.; Peng, S. Drought stress condition increases root to shoot ratio via alteration of carbohydrate partitioning and enzymatic activity in rice seedlings. Acta Physiol. Plant. 2015, 37, 9. [CrossRef]

89. Sehgal, A.; Sita, K.; Siddique, K.H.M.; Kumar, R.; Bhogireddy, S.; Varshney, R.K.; Hanumantha Rao, B.; Nair, R.M.; Vara Prasad, P.V.; Nayyar, H. Drought or/and heat-stress effects on seed filling in food crops: Impacts on functional biochemistry, seed yields, and nutritional quality. Front. Plant Sci. 2018, 9, 1705. [CrossRef]

90. Vollenweider, P.; Gunthardt-Goerg, M.S. Diagnosis of abiotic and biotic stress factors using the visible symptoms in foliage Environ. Pollut. 2005, 137, 455-465. [CrossRef] [PubMed]

91. Huang, H.; Ullah, F.; Zhou, D.-X.; Yi, M.; Zhao, Y. Mechanisms of ROS regulation of plant development and stress responses. Front. Plant Sci. 2019, 10, 800. [CrossRef]

92. Choudhury, F.K.; Rivero, R.M.; Blumwald, E.; Mittler., R. Reactive oxygen species, abiotic stress and stress combination. Plant J. 2017, 90, 856-867. [CrossRef]

93. Apel, K.; Hirt, H. Reactive oxygen species: Metabolism, oxidative stress, and signal transduction. Annu. Rev. Plant Biol. 2004, 55, 373-399. [CrossRef]

94. Das, K.; Roychoudhury, A. Reactive oxygen species (ROS) and response of antioxidants as ROS-scavengers during environmental stress in plants. Front. Environ. Sci. 2014, 2, 53. [CrossRef]

95. Choudhary, A.; Kumar, A.; Kaur, N. ROS and oxidative burst: Roots in plant development. Plant Divers. 2020, 42, 33-43. [CrossRef] [PubMed]

96. Sarwar, M.; Saleem, M.F.; Ullah, N.; Rizwan, M.; Ali, S.; Shahid, M.R.; Alamri, S.A.; Alyemeni, M.N.; Ahmad, P. Exogenously applied growth regulators protect the cotton crop from heat-induced injury by modulating plant defense mechanism. Sci. Rep. 2018, 8, 17086. [CrossRef] 
97. Hasanuzzaman, M.; Nahar, K.; Alam, M.M.; Fujita, M. Exogenous nitric oxide alleviates high temperature induced oxidative stress in wheat (Triticumaestivum L.) seedlings by modulating the antioxidant defense and glyoxalase system. Aust. J. Agric. Res. 2012, 6, 1314-1323.

98. Alamri, S.A.; Siddiqui, M.H.; Al-Khaishanya, M.Y.; Khan, M.N.; Ali, H.M.; Alakeel, K.A. Nitric oxide-mediated cross-talk of proline and heat shock proteins induce thermotolerance in Viciafaba L. Environ. Exp. Bot. 2019, 161, 290-302. [CrossRef]

99. Planchet, E.; Verdu, I.; Delahaie, J.; Cukier, C.; Girard, C.; Morère-Le Paven, M.C.; Limami, A.M. Abscisic acid-induced nitric oxide and proline accumulation in independent pathways under water-deficit stress during seedling establishment in Medicago truncatula. J. Exp. Bot. 2014, 65, 2161-2170. [CrossRef]

100. Brestic, M.; Zivca, M.; Olsovaka, K.; Kalaji, H.M.; Shao, H.; Hakeem, K.R. Heat signaling and stress responses in photosynthesis. In Plant Signaling: Understanding the Molecular Crosstalk; Hakeem, K., Rehman, R., Tahir, I., Eds.; Springer: New York, NY, USA, 2014; pp. 241-256.

101. Misra, A.N. Effect of temperature on chlorophyll degradation of senescing rice leaves. J. Sci. Res. 1981, 3, 9-10.

102. Kong, J.; Dong, Y.; Xu, L.; Liu, S.; Bai, X. Effects of foliar application of salicylic acid and nitric oxide in alleviating iron deficiency induced chlorosis of Arachishypogaea L. Bot. Stud. 2014, 55, 9. [CrossRef]

103. Yang, Q.; He, H.; Li, H.; Tian, H.; Zhang, J.; Zhai, L.; Chen, J.; Wu, H.; Yi, G.; He, Z.H.; et al. NOA1 functions in a temperaturedependent manner to regulate chlorophyll biosynthesis and RuBisCo formation in rice. PLoS ONE 2011, 6, e20015. [CrossRef]

104. Wodala, B.; Deák, Z.; Vass, I.; Erdei, L.; Altorjay, I.; Horváth, F. In vivo target sites of nitric oxide in photosynthetic electron transport as studied by chlorophyll fluorescence in pea leaves. Plant Physiol. 2008, 146, 1920-1927. [CrossRef]

105. Zhang, X.; Wollenweber, B.; Jiang, D.; Liu, F.; Zhao, J. Water deficits and heat shock effects on photosynthesis of a transgenic Arabidopsis thaliana constitutively expressing ABP9, a bZIP transcription factor. J. Exp. Bot. 2008, 59, 839-848. [CrossRef]

106. Hsieh, E.J.; Cheng, M.C.; Lin, T.P. Functional characterization of an abiotic stress-inducible transcription factor AtERF53 in Arabidopsis thaliana. Plant. Mol. Biol. 2013, 82, 223-237. [CrossRef] [PubMed]

107. Wang, P.; Zhu, J.K.; Lang, Z. Nitric oxide suppresses the inhibitory effect of abscisic acid on seed germination by S-nitrosylation of SnRK2 proteins. Plant Signal. Behav. 2015, 10, e1031939. [CrossRef] [PubMed]

108. Uchida, A.; Jagendorf, A.T.; Hibino, T.; Takabe, T.; Takabe, T. Effects of hydrogen peroxide and nitric oxide on both salt and heat stress tolerance in rice. Plant Sci. 2002, 163, 515-523. [CrossRef]

109. Larkindale, J.; Hall, J.D.; Knight, M.R.; Vierling, E. Heat stress phenotypes of Arabidopsis mutants implicate multiple signaling pathways in the acquisition of thermotolerance. Plant Physiol. 2005, 138, 882-897. [CrossRef] [PubMed]

110. Ding, W.; Song, L.; Wang, X.; Bi, Y. Effect of abscisic acid on heat stress tolerance in the calli from two ecotypes of Phragmites communis. Biol. Plant. 2010, 54, 607-613. [CrossRef]

111. Zhang, A.; Jiang, M.; Zhang, J.; Ding, H.; Xu, S.; Hu, X.; Tan, M. Nitric oxide induced by hydrogen peroxide mediates abscisic acid-induced activation of the mitogen-activated protein kinase cascade involved in antioxidant defense in maize leaves. New Phytol. 2007, 175, 36-50. [CrossRef]

112. Sharma, A.; Shahzad, B.; Kumar, V.; Kohli, S.K.; Sidhu, G.P.S.; Bali, A.S.; Handa, N.; Kapoor, D.; Bhardwaj, R.; Zheng, B. Phytohormones regulate accumulation of osmolytes under abiotic stress. Biomolecules 2019, 9, 285. [CrossRef]

113. Pattanagul, W. Exogenous abscisic acid enhances sugar accumulation in rice (Oryza sativa L.) under drought stress. Asian J. Plant Sci. 2011, 10, 212-219. [CrossRef]

114. Liu, L.; Cang, J.; Yu, J.; Wang, X.; Huang, R.; Wang, J.; Lu, B. Effects of exogenous abscisic acid on carbohydrate metabolism and the expression levels of correlative key enzymes in winter wheat under low temperature. Biosci. Biotechnol. Biochem. 2013, 77, 516-525. [CrossRef]

115. Saeedipour, S. Exogenous abscisic acid enhances sugar accumulation in rice (Oryza sativa L.) under salinity. Int. J. Bio Sci. 2014, 4, 249-257.

116. Robertson, A.J.; Ishikawa, M.; Gusta, L.V.; MacKenzie, S.L. Abscisic acid-induced heat tolerance in Bromus inermis leyss cellsuspension cultures (heat-stable, abscisic acid-responsive polypeptides in combination with sucrose confer enhanced thermostability). Plant Physiol. 1994, 105, 181-190. [CrossRef] [PubMed]

117. Khan, A.; Ahmad, M.; Ahmed, M.; Hussain, M.I. Rising atmospheric temperature impact on wheat and thermotolerance strategies. Plants 2021, 10, 43. [CrossRef] [PubMed]

118. Khan, M.N.; Siddiqui, M.H.; Mohammad, F.; Naeem, M. Interactive role of nitric oxide and calcium chloride in enhancing tolerance to salt stress. Nitric Oxide 2012, 27, 210-218. [CrossRef] [PubMed]

119. Zulfiqar, F.; Ashraf, M.; Siddique, K.H.M. Role of Glycine betaine in the thermotolerance of plants. Agronomy 2022, $12,276$. [CrossRef]

120. Allakhverdiev, S.I.; Los, D.A.; Mohanty, P.; Nishiyama, Y.; Murata, N. Glycinebetaine alleviates the inhibitory effect of moderate heat stress on the repair of photosystem II during photoinhibition. Biochim. Biophys. Acta 2007, 1767, 1363-1371. [CrossRef]

121. Hashemi, F.S.G.; Ismail, M.R.; Rafii, M.Y.; Aslani, F.; Miah, G.; Muharam, F.M. Critical multifunctional role of the betaine aldehyde dehydrogenase gene in plants. Biotechnol. Biotechnol. Equip. 2018, 32, 815-829. [CrossRef]

122. Ullah, S.; Egbichi, K.I.; Keyster, M.; Ludidi, N. Nitric oxide influences glycine betaine content and ascorbate peroxidase activity in maize. S. Afr. J. Bot. 2016, 105, 218-225. [CrossRef]

123. Kaplan, F.; Kopka, J.; Haskell, D.W.; Zhao, W.; Cameron, S.K.; Gatzke, N.; Sung, D.Y.; Guy, C.L. Exploring the temperaturestress metabolome of Arabidopsis. Plant Physiol. 2004, 136, 4159-4168. [CrossRef] 
124. Luo, Y.; Li, F.; Wang, G.P.; Yang, X.H.; Wang, W. Exogenously-supplied trehalose protects thylakoid membranes of winter wheat from heat-induced damage. Biol. Plant. 2010, 54, 495-501. [CrossRef]

125. Kosar, F.; Akram, N.A.; Sadiq, M.; Al-Qurainy, F.; Ashraf, M. Trehalose: A key organic osmolyte effectively involved in plant abiotic stress tolerance. J. Plant Growth Regul. 2019, 38, 606-618. [CrossRef]

126. Kong, W.W.; Huang, C.Y.; Chen, Q.; Zou, Y.J.; Zhao, M.R.; Zhang, J.X. Nitric oxide is involved in the regulation of trehalose accumulation under heat stress in Pleurotuseryngii var. tuoliensis. Biotechnol. Lett. 2012, 34, 1915-1919. [CrossRef] [PubMed]

127. Verbruggen, N.; Hermans, C. Proline accumulation in plants: A review. Amino Acids 2008, 35, 753-759. [CrossRef] [PubMed]

128. Chen, T.H.; Murata, N. Glycinebetaine: An effective protectant against abiotic stress in plants. Trends Plant Sci. 2008, 13, 499-505. [CrossRef] [PubMed]

129. Xing, H.; Tan, L.; An, L.; Zhao, Z.; Wang, S.; Zhang, C. Evidence for the involvement of nitric oxide and reactive oxygen species in osmotic stress tolerance of wheat seedlings: Inverse correlation between leaf abscisic acid accumulation and leaf water loss. Plant Growth Regul. 2004, 42, 61-68. [CrossRef]

130. Zhang, Y.; Tan, J.; Guo, Z.; Lu, S.; He, S.; Shu, W.; Zhou, B. Increased abscisic acid level in transgenic tobacco overexpressing 9-cis epoxycarotenoiddioxegenase influences $\mathrm{H}_{2} \mathrm{O}_{2}$ and $\mathrm{NO}$ production and antioxidant defences. Plant Cell Environ. 2009, 32, 509-519. [CrossRef] [PubMed]

131. Ribeiro, D.M.; Desikan, R.; Bright, J.; Confraria, A.; Harrison, J.; Hancock, J.T.; Barros, R.S.; Neill, S.J.; Wilson, I.D. Differential requirement for NO during ABA-induced stomatal closure in turgid and wilted leaves. Plant Cell Environ. 2009, $32,46-57$. [CrossRef] [PubMed]

132. Yan, J.; Tsuichihara, N.; Etoh, T.; Iwai, S. Reactive oxygen species and nitric oxide are involved in ABA inhibition of stomatal opening. Plant Cell Environ. 2007, 30, 1320-1325. [CrossRef]

133. de Pinto, M.C.; Locato, V.; Sgobba, A.; Romero-Puertas, M.D.C.; Gadaleta, C.; Delledonne, M.; De Gara, L. S-nitrosylation of ascorbate peroxidase is part of programmed cell death signaling in tobacco Bright Yellow-2 cells. Plant Physiol. 2013, 163, 1766-1775. [CrossRef]

134. Romero-Puertas, M.C.; Rodríguez-Serrano, M.; Sandalio, L.M. Protein S-nitrosylation in plants under abiotic stress: An overview. Front. Plant Sci. 2013, 4, 373. [CrossRef] 